\title{
PIRACY IN SOMALIA: A LEGAL ANALYSIS CONCERNING THE PROSECUTION OF PIRATE NEGOTIATORS AND PIRATE FACILITATORS UNDER THE CURRENT US AND INTERNATIONAL FRAMEWORK
}

\author{
Graham T. Youngs* \\ I. INTRODUCTION
}

"A pirate, under the laws of nations, is an enemy of the human race. Being the enemy of all, he is liable to be punished by all. . . But piracy, under the law of nations, which alone is punishable by all nations, can only consist in an act which is an offense against all. No particular nation can increase or diminish the list of offenses thus punishable."

- Chief Justice John Marshall

\section{A. Piracy by the Numbers: An Introduction to The Current Piracy Problem}

Piracy off the coast of Somalia remains an issue with implications for the international community generally and for the Somali government specifically. Regardless of its genesis, piracy off the coast of Somalia "has in essence become an organized, lucrative and attractive criminal activity undertaken for heinous ends." Although the number of people being held hostage by pirates is in constant flux, ${ }^{3}$ the piracy problem implicates several enduring issues: the protection of human lives, the maintenance of channels for international commerce, and continuing respect for Somali territorial waters.

\footnotetext{
* Graham Youngs received his J.D. in 2014 from the Indiana University Robert H. McKinney School of Law. He would like to thank Professor Yvonne Dutton for her input and guidance. The author would also like to express his sincere gratitude to the student note candidates, editorial board, and executive board members of the Indiana International and Comparative Law Review (II\&CLR) for their invaluable help during the editing process.

1. United States v. Ali, 885 F. Supp. 2d 17, 27 (D.D.C. July 13, 2012), opinion vacated in part, 885 F. Supp. 2d 55 (D.D.C. July 25, 2012) (citing Ruth Wedgwood, The Revolutionary Martyrdom of Jonathan Robbins, 100 YALE L.J. 229, 230 (1990)).

2. Special Adviser on Legal Issues Related to Piracy off the Coast of Somalia, Report of the Special Adviser to the Secretary-General on Legal Issues Related to Piracy off the Coast of Somalia, 9ף 13, 43, U.N. Doc. S/2011/30 (Jan. 24, 2011) (by Jack Lang) [hereinafter Lang Report].

3. See International Maritime Bureau, Piracy \& Armed Robbery News \& Figures, INT'L CHAMBER OF COMMERCE (Oct. 27, 2012), http://www.icc-ccs.org/piracy-reportingcentre/piracynewsafigures, archived at http://perma.cc/5AUR-KZ7M (The IMB is an apolitical organization charged with "receiving and disseminating reports of piracy and armed robbery 24 hours a day, across the globe.").
} 
The problem of piracy has far-reaching economic implications: an estimated 40 percent of the world's trade is shipped through part of the Indian Ocean, around the Horn of Africa, and into the Red Sea-a route that is rife with Somali pirate attacks. ${ }^{4}$ A report issued by the One Earth Future Foundation (OEF) estimated Somali piracy cost between $\$ 6.6$ and $\$ 6.9$ billion in $2011 .^{5}$ The shipping industry bore 80 percent - or between $\$ 5.3$ and $\$ 5.5$ billion — of that total cost in $2011 .^{6}$ The overall cost of piracy does not appear to be waning in the near future. Due to the rebound in global maritime trade volume, the geographic expansion of piracy, and increasingly sophisticated piracy efforts, some sources suggest that, "[c]onsidering Somali piracy as an increased cost of trade translates into an estimated US\$18 billion yearly loss to the world economy."7

Other sources rely on more optimistic piracy figures from 2012 to suggest that significant progress has been made. ${ }^{8}$ For instance, some figures from the US Navy suggest a 75 percent decline in the number of pirate attacks during 2012 as compared with $2011 .^{9}$ The decline in the number of pirate attacks comes in the wake of a multi-pronged effort from the United States, the UK, NATO, the EU, and the international community - as well as the private sector in general. ${ }^{10}$ The prongs of the effort focus on several categories including diplomatic engagement, military power, collaboration with the private sector, legal enforcement, targeting pirate networks, and the development of the Somali government. ${ }^{11}$ The scope of this Note, however,

4. Remarks of Richard Ottaway, EuR. PARL. DEB. at 144WH (June 14, 2012), archived at http://perma.cc/7FHW-D556.

5. Anna Bowden \& Shikha Basnet, The Economic Cost of Somali Piracy 20111 (One Earth Found. 2011), archived at http://perma.cc/7FHW-D556 [hereinafter BowDEN \& BASNET REPORT] (Total cost was calculated across both government and industry categories, including: labor, prosecutions, organizations, military, ransoms, insurance, security equipment, re-routing, and increased speed.).

6. $I d$.

7. The World Bank Reg'l Vice-Presidency for Afr., The Pirates of Somalia: ENDING THE THREAT, REBUILDING A NATION xxiii (2013), archived at http://perma.cc/78K8WY2 [hereinafter PIRATES OF SOMALIA: ENDING THE THREAT].

8. See Thomas Kelly, Principal Deputy Assistant Sec'y, U.S. Bureau of PoliticalMilitary Affairs, Remarks at Combating Piracy Week in London, United Kingdom (Oct. 25, 2012), archived at http://perma.cc/GL2S-M635 [hereinafter Thomas Kelly Remarks]; see also Ronald K. Noble, INTERPOL Sec'y General, Welcome Address at the Conference on Maritime Piracy Financial Investigations, (Jan. 19-20, 2010), archived at http://perma.cc/F9J3-GKU8 (noting a decrease in the number of pirate attacks in the Indian Ocean during the first quarter of 2012 as compared with the first quarter in 2011).

9. Thomas Kelly Remarks, supra note 8. "In January 2011, pirates held 31 ships and 710 hostages. Today, pirates hold five ships and 143 hostages. That is roughly a 75 percent reduction in ships and hostages held by pirates since January 2011.” Thomas Kelly Remarks, supra note 8; see also Key Figures and Information, EUNAVFOR (Nov. 5, 2012), $\mathrm{http}: / /$ eunavfor.eu/key-facts-and-figures/, archived at http://perma.cc/QT3R-4YDS.

10. Thomas Kelly Remarks, supra note 8.

11. Thomas Kelly Remarks, supra note 8. 
will focus on the legal enforcement issues related to the targeting of pirate networks and the prosecution of pirate negotiators and higher-ranking pirates whose crimes are typically categorized as "white-collar." These white-collar pirates are responsible for providing funding, organizational tools, and political capital. ${ }^{12}$

Legal enforcement, or the use of effective legal prosecution and incarceration to deter piracy, appears to be working to some degree: in 2011 , for example, there were more than 1,000 pirates in custody in twenty countries around the world. ${ }^{13}$ However, not all experts find these numbers convincing-some experts note that as many as nine out of ten pirates captured by States patrolling international waters will be released without being prosecuted. ${ }^{14}$ In a 2011 report on legal issues related to piracy off the coast of Somalia, Special Adviser Jack Lang noted that there has been increased development and sophistication within piracy networks. ${ }^{15}$ In particular, the ability of pirate networks to marshal logistical support for the negotiation of ransoms and the holding of hostages has enabled a larger number of captures and thereby provided networks with a consistent source of revenue. ${ }^{16}$ Irrespective of the number of ships captured, or the economic ramifications of piracy, one conclusion seems clear: "[p]iracy has gone from a fairly ad hoc disorganized criminal endeavor to a highly developed transnational criminal enterprise." 17

\section{B. The Role of Pirate Negotiators and Pirate Facilitators in the Scourge of Piracy}

In some respects, the act of piracy itself has remained unchanged over time: "whether using swords or rocket propelled grenades, a galleon or a fastboat, a sextant or GPS, pirates will always be looking for easy targets and easy profit." ${ }^{18}$ In the seventeenth and eighteenth centuries pirates may have plundered a ship's cargo for an easy profit; today however, human crews are equally valuable because of the availability and willingness of ship owners to pay ransoms. ${ }^{19}$ As a result, pirate networks have made increasing use of pirate negotiators, or "“interpreters,"” to ensure successful

12. See Pirates of Somalia: Ending the Threat, supra note 7, at 6.

13. Thomas Kelly Remarks, supra note 8.

14. Lang Report, supra note 2, at 21; see also Remarks of Richard Ottaway, supra note 4.

15. Lang Report, supra note 2, at 13.

16. Lang Report, supra note 2, at 13.

17. Confronting Global Piracy Hearing Before the Subcomm. on Terrorism, Nonproliferation and Trade of the H. Foreign Affairs Comm. 1 (2011) (statement of Andrew J. Shapiro, Assistant Sec'y, Bureau of Political-Military Affairs), archived at http://perma.cc/G38X-5BQG.

18. Noble, supra note 8.

19. Noble, supra note 8. 
ransom transactions. ${ }^{20}$ Using cell phones and satellite phones, pirate negotiators serve as the liaisons between the owners of hijacked ships and pirate bosses. ${ }^{21}$ Often pirate negotiators serve as the interpreter for several ships, and in some cases may even provide negotiation services to multiple pirate networks simultaneously. ${ }^{22}$ Negotiators must possess the foreign language skills - especially in the English language - to communicate with the ship's owners; moreover, they must possess the intangible social skills necessary to reconcile the interests of all the parties involved to procure a ransom. $^{23}$

The ransom agreements have become increasingly costly for the owners of captured victim ships - based on available data, the OEF calculated statistics for 2011 and concluded that thirty-one ransoms were paid for a total of $\$ 159.62$ million with an average ransom payment of $\$ 4.97$ million. ${ }^{24}$ Pirate negotiators are well compensated for their servicesin fact, a negotiator typically receives twice the share of a regular pirate guard. ${ }^{25}$ In addition to the salary a negotiator receives from his or her boss, some negotiators are able to procure additional, secret funds by having the shipping company wire them money directly into a foreign account. ${ }^{26}$ For example, one particularly notorious pirate negotiator, Looyaan Si'id Barte, reportedly served as a negotiator in twenty pirate attacks between January 2009 and April 2011. ${ }^{27}$ Based on a report from the Monitoring Group on Somalia and Eritrea, Looyaan received an estimated $\$ 500,000$ for his negotiation services during that period of time. ${ }^{28}$

Other high-ranking, white-collar pirates also play a pivotal role in the piracy model. As a practical matter, the Somali hijack-for-ransom business model only exists insofar as pirate networks have consistent shore locations to anchor the captive ships during ransom negotiations. ${ }^{29}$ Access to space on the Somali coast is necessary to protect captive ships from national and international law enforcement as well as rival piracy groups. ${ }^{30}$ In exchange for anchorage locations, Somali pirates typically must pay an anchorage fee to local insurgent groups, or bribe the local government. ${ }^{31}$ Thus, local

20. Monitoring Group on Somalia and Eritrea, Report pursuant to S.C. Res. 1916, U.N. Doc. S/2011/433 (Jul. 18, 2011) [hereinafter Report on Somalia and Eritrea].

21. $I d$.

22. Id. at 221.

23. Id. at 36 .

24. BOWDEN \& BASNET REPORT, supra note 5; c.f. Noble, supra note 8 (indicating that ransoms in 2011 amounted to $\$ 135$ million).

25. Report on Somalia and Eritrea, supra note 20, at 221.

26. Report on Somalia and Eritrea, supra note 20, at 221.

27. Report on Somalia and Eritrea, supra note 20, at 222.

28. Report on Somalia and Eritrea, supra note 20, at 223.

29. Pirates of Somalia: Ending the Threat, supra note 7, at xxiv.

30. Pirates of Somalia: Ending the Threat, supra note 7, at xxiv.

31. Pirates of Somalia: Ending the Threat, supra note 7, at xxiv. 
political figures play an indirect, yet powerful role in the viability of Somali piracy; and they are compensated accordingly. ${ }^{32}$ It is estimated that commanders and instigators in Somali piracy business split 70 to 86 percent of piracy proceeds with these stakeholders, without support of whom anchorage of hijacked boats would not be feasible." ${ }^{33}$ Generally speaking then, the category of individuals who facilitate acts of piracy, whether directly or indirectly, is very broad. It includes not only those individuals who instigate and command piracy operations, but also those who supply political capital $^{34}$ and share profits with the pirates themselves. A staggering majority of the piracy profits - up to an estimated 86 percent - end up compensating the individuals who supply political capital. ${ }^{35}$

Certainly the ability of international forces to prosecute pirate negotiators, as well as those who provide political capital to pirate networks, would begin to address the root of the piracy problem rather than the symptoms. This recognition has led to increased efforts to combat piracy at its source. ${ }^{36}$ For example, Contact Group on Piracy off the Coast of Somalia created Working Group 5 which, under the guidance of Italy, "coordinates international efforts to identify and disrupt the financial networks of pirate leaders and their financiers. ${ }^{, 37}$ Regional efforts have also culminated in the creation of the Regional Anti-Piracy Prosecutions and Intelligence Co-ordination Centre (RAPPICC) located near Victoria in Seychelles. ${ }^{38}$ The Centre will seek to separate pirate foot soldiers from the

32. Pirates of Somalia: Ending the Threat, supra note 7, at xxiv.

33. Pirates of Somalia: Ending the Threat, supra note 7, at xxiv, xxv.

34. Pirates of Somalia: Ending the Threat, supra note 7 , at 7 (including officials, militia commanders, religious leaders, members of local communities, clan representatives).

35. Pirates of Somalia: Ending the Threat, supra note 7, at 8. "After carefully calibrating the returns to labor and capital that compensate participants for high risks involved in pirate ventures, it was found that up to 86 percent of ransom proceeds go to remunerate individuals, inside and outside the industry, whose political and social connections allow Somali piracy to thrive." Pirates of Somalia: Ending the Threat, supra note 7 , at 8 .

36. Thomas Kelly Remarks, supra note 8; see also S.C. Res. 2020, ๆ 5, U.N. Doc. S/RES/2020 (Nov. 22, 2011) ("Recognizing the need to investigate and prosecute not only suspects captured at sea, but also anyone who incites or intentionally facilitates piracy operations, including key figures of criminal networks involved in piracy who illicitly plan, organize, facilitate, or finance and profit from such attacks . ...”) (alteration added).

37. Working Group 5, Contact Group on Piracy off the CoAst of Somalia, http://www.thecgpcs.org/work.do?action=workAd (last visited Nov. 3, 2012, archived at http://perma.cc/TSE3-BDWC) (Working Group 5 has worked with INTERPOL to develop a customized Piracy database designed to provide information to law enforcement agencies across the globe as a means of facilitating piracy investigations); Thomas Kelly Remarks, supra note 8 .

38. Thomas Kelly Remarks, supra note 8; see also Regional Anti-Piracy Prosecutions and Intelligence Co-ordination Centre (RAPPICC), OCEANS BEYOND PIRACY, http://oceansbeyondpiracy.org/matrix/activity/regional-anti-piracy-prosecutions-intelligenceco-ordination-centre-rappicc (last visited Nov. 5, 2012, archived at http://perma.cc/FZE4- 
higher-ups; indeed, RAPPICC will focus its efforts on facilitating the capture and prosecution of financers, investors, instigators, and ringleaders involved in Somali piracy. ${ }^{39}$

The United States, too, has increased efforts to disrupt pirate networks and prosecute high-ranking pirates. As former Secretary of State Hillary Clinton opined, "we may be dealing with a 17 th century crime, but we need to bring 21 st century solutions to bear." ${ }^{40}$ In an effort to make kidnappings less profitable for pirates, the United States has begun to prosecute midlevel pirate negotiators. Highlighting this effort are the recent prosecutions of two pirate negotiators: Mohammad Saaili Shibin and Ali Mohamed Ali.

On April 13, 2011, Mohammad Saaili Shibin had his initial appearance in the US District Court for the Eastern District of Virginia after his arrest in Somalia and extradition to the United States. ${ }^{41}$ On August 13, 2012, Shibin received ten concurrent and two consecutive life sentences from a US federal court for his role as a negotiator in the hijacking of the German-owned M/V/ Marida Marguerite and the Quest, a US-flagged vessel with four US citizens aboard. ${ }^{42}$ Following these convictions, Shibin filed an appeal with the US Fourth Circuit Court of Appeals. ${ }^{43}$ In his appeal, Shibin argued that his convictions should be overturned because he never negotiated while personally on the high seas. ${ }^{44}$ The Fourth Circuit rejected this argument, holding that "conduct violating Article 101(c) does not have to be carried out on the high seas, but it must incite or intentionally facilitate acts committed against ships, persons, and property on the high seas." ${ }^{45}$ Consequently, the Fourth Circuit upheld Shibin's conviction. ${ }^{46}$

The second case commenced in April of 2011 when Ali Mohamed Ali was arrested at Dulles International Airport as he made his way to an education conference. ${ }^{47}$ Later that month, on April 29th, a grand jury

M784).

39. Thomas Kelly Remarks, supra note 8; see also Regional Anti-Piracy Prosecutions and Intelligence Co-ordination Centre (RAPPICC), supra note 38.

40. Hillary Rodham Clinton, Sec'y of State, Remarks at the Announcement of CounterPiracy Initiatives (Apr. 15, 2009), archived at http://perma.cc/P5BZ-XY6Q.

41. Bruce Zagaris, U.S. Indicts Somali Hostage Negotiators after FBI Snatches Him in Somalia, 27 INT'L ENFORCEMENT L. REP. 752 (2011); see also Keith Johnson, FBI Snatches Alleged Pirate Inside Somalia, WALl StReET Journal (Apr. 14, 2011), http://online.wsj.com/article/SB10001424052748704547804576261301548767880.html\#, archived at http://perma.cc/5VF8-3RR3.

42. Press Release, U.S. Attorney's Office Eastern District of Virginia, Alleged Somali Hostage Negotiator Charged with Piracy, Kidnapping Charges (Apr. 13, 2011); United States v. Shibin, 722 F.3d 233, 235 (4th Cir. 2013).

43. Brief of Defendant-Appellant, United States v. Shibin, 722 F.3d 233 (4th Cir. 2013) (No. 12-4652) [hereinafter Shibin Brief], archived at http://perma.cc/NHD8-ED4P.

44. Id.

45. Shibin, 722 F.3d at 241.

46. Id. at 249 .

47. Somali Man Arrested for Negotiating Ransom of Danish Ship, Maritime ExECUTIVE (Apr. 25, 2011), http://www.maritime-executive.com/article/somali-man-arrested-for- 
charged Ali with conspiracy to commit piracy under the law of nations; aiding and abetting piracy; an attack to plunder a vessel and aiding and abetting; and hostage taking and aiding and abetting. ${ }^{48}$ The arrest stemmed from Ali's role as a ransom negotiator in the hijacking of the M/V CEC Future, a Bahamian-flagged cargo ship owned by Clipper Group A/S, a Danish company. ${ }^{49}$ At the district court level, Judge Ellen Huevelle granted, in part, Ali's motion to dismiss charges of aiding and abetting piracyruling that such conduct is limited to events that occur on the high seas. ${ }^{50}$ Ali has yet to stand trial for any piracy charges; however, the US Court of Appeals for the District of Columbia found that Ali could be charged as a pirate notwithstanding the fact that his acts of facilitating piracy likely did not occur on the high seas. ${ }^{51}$

\section{The Current Issues Associated with the Prosecution of High-Ranking Pirates}

The arrests and subsequent prosecutions of both Shibin and Ali are novel in two respects. First, both cases involve the prosecution of individuals serving as negotiators, a role that the United States has not sought to prosecute before 2011. ${ }^{52}$ According to US Attorney for the Eastern District of Virginia Neil H. MacBridge, Shibin's arrest marks the first time that the US government has prosecuted an alleged pirate acting in a leadership role as a hostage negotiator. ${ }^{53}$ Second, Ali's case marks the first time that the US government has relied solely on universal jurisdiction to prosecute a Somali pirate. ${ }^{54}$ At the district court level, the Shibin and Ali cases produced seemingly divergent results. Indeed, facing charges that would carry a mandatory life sentence, Ali was released on bail after a contentious status hearing conducted on July 20, 2012, drawing a bemused remark from one commentator: "II can't think of any case in U.S. history or in any other Somali pirate trial in the world where an alleged pirate has

negotiating-ransom-of-danish-ship, archived at http://perma.cc/ZZ95-F7Y6.

48. Grand Jury Indictment, United States v. Ali, 2011 WL 2731965 (D.D.C.) (No. 1100106).

49. United States v. Ali, 870 F. Supp. 2d 10, 15 (D.D.C. 2012).

50. United States v. Ali, 885 F. Supp. 2d 17, 21 (D.D.C. 2012), vacated in part, 885 F. Supp. 2d 55 (D.D.C. 2012) rev'd in part, 718 F.3d 929 (D.C. Cir. 2013), and aff'd in part, 718 F.3d 929 (D.C. Cir. 2013).

51. Ali, 718 F.3d at 947.

52. Press Release, U.S. Attorney's Office Eastern District of Virginia, supra note 42.

53. Press Release, U.S. Attorney's Office Eastern District of Virginia, supra note 42.

54. Eugene Volokh, From Prof. Eugene Kontorovich, About Today's Piracy Decision, VOLOKH CONSPIRACY (July 12, 2012, 5:50 PM), http://www.volokh.com/2012/07/13/fromprof-eugene-kontorovich-about-todays-piracy-decision/, archived at http://perma.cc/7PDYJ7KA; Jon Bellish, A High Seas Requirement for Pirate Facilitators Under UNCLOS?, VIEW From ABOve (Aug. 16, 2012), http://djilp.org/2449/a-high-seas-requirement-forpirate-facilitators-under-unclos/, archived at http://perma.cc/3M6H-FWKS. 
been allowed out on bail pending trial. ${ }^{, 55}$ However, recent rulings ${ }^{56}$ at the federal appellate level have seemingly solidified the legality of prosecuting pirate negotiators for the time being - it seems that the United States can prosecute Somali pirate negotiators, even if the only basis for jurisdiction is universality. ${ }^{57}$

This Note attempts to provide some background to US efforts to prosecute pirate negotiators and high-ranking pirates. It dissects the arguments surrounding the question of whether acts of negotiation must themselves be committed on the high seas - referred to throughout this Note as the "high seas" $" 58$ requirement. ${ }^{59}$ Part II begins with the piracy provision in the US Constitution and traces its evolution through legislative enactments and case law. Part III examines the international framework governing the law of piracy to determine the "law of nations" definition of piracy as referred to in 18 U.S.C. $§ 1651$. Specifically, Part III considers the Harvard Research in International Law Draft Convention on Piracy (Harvard Draft Convention), the 1958 Geneva Convention on the High Seas, (High Seas Convention) and the United Nations Convention on the Law of the Sea (UNCLOS). Then, in Part IV, this Note analyzes the legality of prosecuting pirate negotiators by viewing current cases through the prism of the domestic and international framework delineated in Part III. In particular, Part IV engages in a comparative analysis of the arguments raised by the parties involved in the prosecutions of Ali Mohamed Ali and Mohammad Saaili Shibin - in light of the requirements of 18 U.S.C. $\S \S$ 1651 and 2, UNCLOS Article 101(c), and recent federal appellate

55. Carrie Johnson, Judge Orders Release of Man Accused of Negotiating on Behalf of Somali Pirates, NPR (July 24, 2012), http://www.npr.org/blogs/thetwoway/2012/07/24/157320860/judge-orders-release-of-man-accused-of-negotiating-on-behalfof-somali-pirates, archived at http://perma.cc/BSX5-CR6T.

56. United States v. Shibin, 722 F.3d 233 (4th Cir. 2013); Ali, 718 F.3d 929.

57. See generally Shibin, 722 F.3d 233; Ali, 718 F.3d 929.

58. The term "high seas" has a particular geographic meaning within the context of the United Nations Convention on the High Sea. The "high seas" includes the sea not deemed to be within state territorial jurisdiction. Regarding territorial jurisdiction, article 3 provides: "Every State has the right to establish the breadth of its territorial sea up to a limit not exceeding 12 nautical miles, measured from baselines determined in accordance with this Convention." United Nations Convention on the Law of the Sea art. 3, Dec. 10, 1982, 1833 U.N.T.S. 397 [hereinafter UNCLOS].

59. A second, related question asks whether acts of negotiation themselves constitute piracy, or if piracy is limited to robbery on the high seas; however, this issue is outside the scope of this Note. This issue came to a head in United States v. Dire, and it appears as though the Supreme Court will not weigh in on the matter. 680 F.3d 446 (4th Cir. 2012); see Lyle Denniston, Piracy and the Court-Act II, SCOTUS Blog (Oct. 21, 2012, 9:06 PM), http://www.scotusblog.com/2012/10/piracy-and-the-court-act-ii/, archived at http://perma.cc/X4SW-KM66; Julia Zebley, Supreme Court Rejects Maritime Piracy Petitions, JURIST (Jan. 23, 2013), http://jurist.org/paperchase/2013/01/supreme-court-rejectsmaritime-piracy-petitions.php, archived at http://perma.cc/VW6D-ARKD. 
decisions.

Finally, informed by the discussion of the Shibin and Ali cases, Part V discusses this Note's recommendations. This Note concedes that, as a matter of law, it is likely permissible to charge and prosecute individuals who facilitate acts of piracy, but never themselves enter the high seas. However, this Note cautions against pursuing such prosecutions. Instead of prosecuting pirate facilitators in US federal courts, this Note recommends that the United States defer to the international community to prosecute pirate negotiators and facilitators. First, this position is supported by the rationales underlying the exercise of universal jurisdiction. Second, deferring to the international community to prosecute high-ranking pirates would foster respect for Somali territorial jurisdiction by enhancing predictability and preventing the slippery slope towards potentially absurd prosecutions. Simply put, using US federal courts to prosecute high-ranking Somali pirates is not a sustainable anti-piracy model.

\section{BACKGROUND TO THE LEGAL FRAMEWORK FOR PIRACY LAW IN THE UNITED STATES}

\section{A. Piracy under The US Constitution: The "Define and Punish" Clause}

Article I of the US Constitution vests power with the US Congress "[t]o define and punish Piracies and Felonies committed on the high seas, and Offenses against the Law of Nations. ${ }^{" 60}$ Clause ten addresses three discrete classes of crimes: "universal jurisdiction (piracies), extraterritorial crimes (felonies on the high seas), and violations of international law." ${ }^{.61}$ As commentators have argued, the history and text of clause ten suggest that piracy was considered a unique crime precisely because it was subject to universal jurisdiction. ${ }^{62}$

On its face, it seems odd that the language of clause ten would use both "piracies" and "felonies" because in 1776 the term "felony" would have included the entire category of crimes labeled "piracy." "Therefore, it is significant that the drafters ${ }^{64}$ of clause ten used the terms "piracies" and "felonies," and thereby created a "double redundancy." 65 Assuming that

60. U.S. Const. art. I, $\S 8$, cl. 10.

61. Eugene Kontorovich, The "Define and Punish" Clause and the Limits of Universal Jurisdiction, 103 Nw. U. L. REV. 149, 150-51 (2009).

62. Id.

63. Id. at 160 .

64. Id. at 164 (citing James Madison, Notes of Debates in the Federal Convention OF 1787, at 473-74 (Adrienne Koch ed., 1966)) (noting that "felony at common law" was a vague term, but not so with piracy, and referring to historic statutes on the subject).

65. Kontorovich, supra note 61 , at 160 ("By the late seventeenth century, felony had come to mean any very serious crime, especially those punishable by death." (citing 4 William Blackstone, Commentaries 71 (writing that statutes have made piracy a 
Constitutional construction requires giving each word meaning, if "Offenses" and "Felonies" were categorically equivalent to "Piracies,"then the word "Piracies" would be rendered superfluous. ${ }^{66}$ That is to say, if all "piracies" could be referred to as "felonies," then use of the word "piracies" would be meaningless - an interpretation that does not comport with a fundamental tenant of constitutional construction: words have meaning. Constitutional interpretation requires interpreting the language from clause ten as having some non-redundant meaning; as commentators have observed, it requires inquiry into why the Constitution might treat piracy differently from other felonies and other offenses against the law of nations. ${ }^{67}$ The fundamental difference between "piracies" and "felonies" and "other offenses" is that piracy has a unique jurisdictional scope.

In The Federalist 42, James Madison briefly addressed the respective categories of "piracies," felonies on the high seas," and "offenses against the law of nations." 68 Madison briefly discussed the meaning of "piracies" which appears to simply anticipate the establishment of courts. ${ }^{69} \mathrm{He}$ provided the following comments:

The provision of the federal articles on the subject of piracies and felonies extends no further than to the establishment of courts for the trial of these offenses. The definition of piracies might, perhaps, without inconveniency, be left to the law of nations; though a legislative definition of them is found in most municipal codes. $^{70}$

Madison was able to provide a more concrete definition of "felonies on the high seas":

Felony is a term of loose signification, even in the common law of England; and of various import in the statute law of that kingdom. But neither the common nor the statute law of that, or of any other nation, ought to be a standard for the proceedings of this, unless previously made its own by legislative adoption. The meaning of the term, as defined in the codes of the several States, would be as impracticable as the former would be a dishonorable and illegitimate guide. It is not precisely the same in any two of the States; and varies in each with every revision of its criminal laws.

\footnotetext{
"felony" in English law)).

66. Kontorovich, supra note 61 , at 164.

67. Kontorovich, supra note 61 , at 164.

68. The Federalist No. 42 (James Madison).

69. Id.

70. Id.
} 
For the sake of certainty and uniformity, therefore, the power of defining felonies in this case was in every respect necessary and proper. ${ }^{71}$

Finally, regarding offenses against the law of nations, Madison had the following to say: "These articles contain no provision for the case of offenses against the law of nations; and consequently leave it in the power of any indiscreet member to embroil the Confederacy with foreign nations." ${ }^{, 72}$

\section{Traditional Sources of Jurisdiction}

There are four traditional theories of jurisdiction under the law of nations: territorial, national, passive personality, and protective jurisdiction. ${ }^{73}$ Territorial jurisdiction - the most essential manifestation of state sovereignty - allows a state to exercise jurisdiction over conduct occurring within its own territory, or on ships that it has registered. ${ }^{74}$ States, however, may also exercise extraterritorial jurisdiction. The national principle for jurisdiction allows a state to exercise jurisdiction over the conduct of its own nationals even if such conduct occurs outside its own territory; similarly, the passive personality theory allows a state to exercise jurisdiction over individuals who commit criminal acts against its citizens. ${ }^{75}$ The national principle and the passive personality theory are inversely related - the national theory conditions jurisdiction on the nationality of the criminal actor; conversely, the passive personality theory conditions jurisdiction on the nationality of the victim. ${ }^{76}$ Finally, under the protective principle for jurisdiction, a state may exercise jurisdiction over conduct outside its territory that is directed against a critical state interest. ${ }^{77}$ For example, an anti-trust conspiracy directed against a state's interest would likely constitute a basis for the exercise of jurisdiction under the protective

71. Id.

72. $I d$.

73. United States v. Hasan, 747 F. Supp. 2d 599, 606 (E.D. Va. 2010), aff'd sub nom. United States v. Dire, 680 F.3d 446 (4th Cir. 2012) (citing Restatement (ThiRd) of Foreign Relations LaW of the United States § 402(1)-(2) (1986)).

74. Id.

75. Id. (citing Restatement (ThiRd) of Foreign Relations LAW of the United STATES § 402(1)-(2) (1986)).

76. Id.; see also Chau Han Mow v. United States, 730 F.2d 1308, 1311 (9th Cir. 1984) (applying the protective personality principle to obtain subject matter jurisdiction over acts of conspiracy).

77. See United States v. Yousef, 327 F.3d 56, 110 (2d Cir. 2003) (applying the "protective principle" of jurisdiction to a defendant who planned to bomb United States commercial aircraft abroad). 
principle. $^{78}$

\section{Universal Jurisdiction: General Piracy Versus Municipal Piracy}

\section{a. General Piracy}

The crime of piracy, from as early as the seventeenth century, was considered a crime with a unique jurisdictional scope. ${ }^{79}$ In large part, the unique jurisdictional scope of piracy comes from a bifurcated meaning of the very term "piracy." it relates to a crime under public international law. ${ }^{81}$ In a different sense, the term "piracy" can refer to a crime under municipal law. ${ }^{82}$ General piracy is piracy in violation of the law of nations, whereas municipal piracy is piracy in violation of some State's domestic law. ${ }^{83}$ In this Note, municipal piracy will refer to the US domestic piracy provision contained in section 1651. Use of the term piracy in the general piracy sense comes from the historic notion that piracy is a crime subject to universal jurisdiction. ${ }^{84}$ Indeed, pirates have traditionally been referred to as "hostis humani generis," a phrase meaning "common enemies of all mankind." 85 Since the early seventeenth century, piracy has been considered the only universal jurisdiction offense. ${ }^{86}$ General piracy, as an international crime, grants all States jurisdiction over the pirate, regardless of where the pirate was captured, so long as it was on the high seas. ${ }^{87}$

There are at least two main rationales for allowing universal jurisdiction over the crime of piracy. The first rationale relies on a logical connection between the crime of piracy and the geographical location of

78. Eugene Kontorovich, The Piracy Analogy: Modern Universal Jurisdiction's Hollow Foundation, 45 HARV. INT'L L.J. 183, 189 (2004).

79. Id.

80. Id.

81. Edwin D. Dickinson, Is the Crime of Piracy Obsolete?, 38 HARV. L. REV. 334, 335 (1925); Kontorovich, supra note 61, at 164.

82. Dickinson, supra note 81; Kontorovich, supra note 61, at 164. Indeed, the Harvard Researchers who organized the Harvard Draft Convention on Piracy recognized this distinction: "[P]iracy under the law of nations and piracy under municipal law are entirely different subject matters and ... there is no necessary coincidence of fact-categories covered by the term in any tow systems of law." Alfred Rubin, The LAw OF Piracy 336 (2d ed. 1998) (citing J. Bingham et al., Harvard Research in International Law: Draft Convention on Piracy, 26 Am. J. INT'L L. Supp. 739, 749 (1932)) (alterations added).

83. United States v. Dire, 680 F.3d 446, 455 (4th Cir. 2012), cert. denied, 133 S. Ct. 982 (2013).

84. Dickinson, supra note 81 ; Kontorovich, supra note 61 , at 164.

85. RUBIN, supra note 82 , at 17 ; see id. at $91-95$ for a description of the origins of the phrase. See also EdWARd CoKe, 3 Institutes on the LAWs of ENGLAND 113 (1797).

86. Kontorovich, supra note 61, at 164; Kontorovich, supra note 78, at 190.

87. Dickinson, supra note 81 , at 356. 
"high seas:" pirates, who operate on the high seas, endanger the trade and commerce of all countries because they do not discriminate among their victims based on nationality. ${ }^{88}$ For example, "cargo ships are usually owned by a corporation in one state, fly the flag of a second state, and carry cargo destined for multiple other states." ${ }^{, 89}$ A pirate attack on such a cargo ship would simultaneously affect the interests of all three States. Consequently, because all States have an interest in maintaining safe channels for commerce on the high seas, it follows that all States should be able to prosecute pirates who may threaten that commerce.

Second, pirates, by definition, do not serve the interests of any home country; consequently, no government will protest if another country seeks to prosecute individuals caught in the act of piracy. ${ }^{90}$ Other commentators have articulated this rationale in a slightly different way: when individuals commit acts of piracy they lose their nationality by their very acts - they become "de-nationalized." A pirate who has been de-nationalized can no longer be subjected to the national jurisdiction of his or her former state of nationality; thus, other countries must be able to assert jurisdiction to fill this jurisdictional void. $^{92}$ Regardless of the rationale, the essence of universal jurisdiction remains largely the same: pirates do not have allegiance to any one State, and because they harm the interests of multiple States, they are considered to be the enemy of all States. ${ }^{93}$

\section{B. US Municipal Piracy Laws}

US municipal piracy, on the other hand, can consist of virtually any offense the US Congress chooses to define through statute; however, it is possible for a crime to be labeled "piracy" under municipal law but still not be a crime subject to universal jurisdiction. ${ }^{94}$ In other words, labeling a crime "piracy" does not automatically qualify that crime as one subject to universal jurisdiction. ${ }^{95}$ A State may only invoke universal jurisdiction over general piracy when its municipal statute reflects the definition of piracy derived from international consensus. ${ }^{96}$ That is to say, a State may dub any

88. Eugene Kontorovich, "A Guantanamo on the Sea": The Difficulty of Prosecuting Pirates and Terrorists, 98 CAL. L. REV. 243, 252 (2010) (citing United States v. Yousef, 327 F.3d 56, 104 (2d Cir. 2003)).

89. Id.

90. Id.

91. Robin Geiss \& Anna Petrig, Piracy and Armed Robbery at Sea 146 (2011).

92. Id.

93. RuBIN, supra note 82, at 17.

94. Kontorovich, supra note 61 , at 166 ; Kontorovich, supra note 78 , at 190; United States v. Hasan, 747 F. Supp. 2d 599, 606 (E.D. Va. 2010) (citing Dole v. New England Mut. Marine Ins. Co., 7 F. Cas. 837, 847 (C.C.D. Mass. 1864)).

95. Kontorovich, supra note 61 , at 166.

96. See Hasan, 747 F. Supp. 2d at 606. 
conduct piracy, but that State only obtains universal jurisdiction over the conduct when it is also defined by the law of nations as piracy. For example, the US Congress could codify a crime with the elements of common law battery and call it "piracy;" but labeling the crime "piracy" would not give US courts jurisdiction over foreigners who commit batteries on the high seas. Universal jurisdiction only arises to the extent that the US municipal statute and the "law of nations" overlap. ${ }^{97}$

\section{The Act of 1790}

On April 30, 1790, Congress passed its first substantive piracy provision. ${ }^{98}$ Congress passed the Act of 1790 "for the punishment of certain crimes against the United States." Section 8 of the Act dealt specifically with the crime of piracy, providing:

That if any person or persons shall commit upon the high seas, or in any river, haven, basin or bay, out of the jurisdiction of any particular state, murder or robbery, or any other offence which if committed within the body of a county, would by the laws of the United States be punishable with death; or if any captain or mariner of any ship or other vessel, shall piratically and feloniously run away with such ship or vessel, or any goods or merchandise to the value of fifty dollars, or yield up such ship or vessel voluntarily to any pirate; or if any seaman shall lay violent hands upon his commander, thereby to hinder and prevent his fighting in defence of his ship or goods committed to his trust, or shall make a revolt in the ship; every such offender shall be deemed, taken and adjudged to be a pirate and felon, and being thereof convicted, shall suffer death. . . $^{100}$

Section 8 can be divided into three different classes of piracy, each with a distinct definition. ${ }^{101}$ All three definitions, however, penalize the crime of piracy with a sentence of death. ${ }^{102}$ The first class of piracy discussed in section 8 includes "any persons" who commit acts of piracy. ${ }^{103}$

97. Id.

98. Act of Apr. 30, 1790, § 8, 1 Stat. 112 [hereinafter Act of 1790].

99. Id.

100. Id.

101. Dickinson, supra note 81 , at 343 .

102. Dickinson, supra note 81 , at 343 .

103. "That if any person or persons shall commit upon the high seas, or in any river, haven, basin or bay, out of the jurisdiction of any particular state, murder or robbery, or any 
The second class includes "any captain or mariner of any ship or other vessel." 104 Finally, the third class includes "any seaman" who "shall lay violent hands upon his commander." 105 The section 8 definition of piracy appeared to recognize the applicability of universal jurisdiction to the crime of piracy for the prosecution of individuals from any country; however, the failure of section 8 to criminalize piracy consistent with international law limited its jurisdictional scope. ${ }^{106}$ Indeed, the problems with section 8 of the Act of 1790 became evident in the Supreme Court case of United States $v$. Palmer which will be discussed infra in Part C. ${ }^{107}$

\section{The Congressional Act of 1819}

On March 3, 1819, the year after the United States v. Palmer decision, Congress passed the Congressional Act of $1819 .{ }^{108}$ The Act of 1819 was a Congressional Act "to protect the commerce of the United States, and punish the crime of piracy." " 109 Section 5 of the Act of 1819 dealt with piracy in particular, criminalizing the following acts:

That if any person or persons whatsoever, shall, on the high seas, commit the crime of piracy, as defined by the law of nations, and such offender or offenders, shall afterwards be brought into or found in the United States, every such offender or offenders shall, upon conviction thereof, before the circuit court of the United States for the district into which he or they may be brought, or in which he or they shall be found, be punished with death. ${ }^{110}$

The initial Act of 1819 was limited in time to one year, but was

other offence which if committed within the body of a county, would by the laws of the United States be punishable with death ...." Act of 1790, supra note 98 (alteration added).

104. " $[\mathrm{O}] \mathrm{r}$ if any captain or mariner of any ship or other vessel, shall piratically and feloniously run away with such ship or vessel, or any goods or merchandise to the value of fifty dollars, or yield up such ship or vessel voluntarily to any pirate . . . " Act of 1790, supra note 98 (alterations added).

105. " $[\mathrm{O}] \mathrm{r}$ if any seaman shall lay violent hands upon his commander, thereby to hinder and prevent his fighting in defence of his ship or goods committed to his trust, or shall make a revolt in the ship; every such offender shall be deemed, taken and adjudged to be a pirate and felon, and being thereof convicted, shall suffer death; and the trial of crimes committed on the high seas, or in any place out of the jurisdiction of any particular state, shall be in the district where the offender is apprehended, or into which he may first be brought." Act of 1790, supra note 98 (alteration added).

106. Dickinson, supra note 81 , at 344 .

107. United States v. Palmer, 16 U.S. 610, 611 (1818).

108. Act of Mar. 3, 1819, ch. 77, 3 Stat. 510 [hereinafter Act of 1819].

109. R. Chuck Mason, Cong. Research Serv., R41455, Piracy: A Legal Definition 2 (2010).

110. Act of 1819 , supra note $108, \S 5$. 
eventually continued by section 2 of an act passed on May $15,1820 .^{111}$

The Act of 1819 marked a shift from a specific definition of piracy, as initially enunciated in the 1790 Act, to a definition of piracy by reference to the "law of nations." 112 Under the 1790 Act a crime of robbery-committed by a person on the high seas, on board a foreign vessel, and against a person from a foreign state-would not have qualified as piracy within the statutory definition. In other words, the Act of 1790 limited the power of US courts to exercise universal jurisdiction over individuals deemed to be pirates by virtue of the "law of nations." The 1819 Act, by reference to the "law of nations," ameliorated problems with the 1790 Act by expanding the US municipal statute to track international developments in the definition of piracy. ${ }^{113}$

\section{The Act of 1820}

In 1820 , Congress reenacted the Act of 1819 as "[a]n act to protect the commerce of the United States, and punish the crime of piracy." 114 Section 2 of the 1820 Act largely replicated section 5 of the 1819 Act by reinstating that section; section 2 provided "[t]hat the fifth section of the said act [of 1819] be, and the same is hereby continued in force, as to all crimes made punishable by the same, and heretofore committed, in all respects or fully as if the duration of the said section had been without limitation." 115

In addition, section 3 of the Act of 1820 explicitly addressed piracy in the following way:

That, if any person shall, upon the high seas, or in any open roadstead, or in any haven, basin, or bay, or in any river

111. RuBIN, supra note, 82, at 144-45 (citing Act May 25, 1820, ch. 113, 3 Stat. 600,16th Cong., 1st Sess.).

112. RUBIN, supra note, 82 , at 145.

113. The court in United States v. Chapels referred to the Act of 1790 as containing an omission, therefore requiring an additional congressional statute to amend the problem: "To supply this omission, a new provision was deemed to be necessary; and it is understood, that with this intention the last congress adopted the 5th section of the 'act to protect the commerce of the United States, and punish the crime of piracy,' passed on the $3 \mathrm{~d}$ of March, 1819 [3 Stat. 513].” United States v. Chapels, 25 F. Cas. 399 (C.C.D. Va. 1819).

114. Act of May 15, 1820, ch. 77, $\S 1-2,3600$ Stat. [hereinafter Act of 1820]. It provided that section 5 of the Act of 1819 should be "continued in force" without limitation as to time "as to all crimes made punishable by the same, and heretofore committed." RUBIN, supra note 82, at 381. Notably, the Act of 1820 made it "piracy" for an American to be engaged in the international slave trade which presumably represented an attempt "to develop the international law, the 'law of nations,' by changing the municipal law of the United States, with the goal that the international community would reciprocate; however, to that extent it failed." Id. at 163.

115. RuBIN, supra note 82, at 381. 
where the sea ebbs and flows, commit the crime of robbery, in or upon any ship or vessel, or upon any of the ship's company of any ship or vessel, or the lading thereof, such person shall be adjudged to be a pirate: and, being thereof convicted before the circuit court of the United States for the district into which he shall be brought, or in which he shall be found, shall suffer death. And if any person engaged in any piratical cruise or enterprise, or being of the crew or ship's company of any piratical ship or vessel, shall land from such ship or vessel, and, on shore, shall commit robbery, such person shall be adjudged a pirate: and on conviction thereof before the circuit court of the United States for the district into which he shall be brought, or in which he shall be found, shall suffer death:

Provided, That nothing in this section contained shall be construed to deprive any particular state of its jurisdiction over such offences, when committed within the body of a county, or authorize the courts of the United States to try any such offenders, after conviction or acquittance, for the same offence, in a state court. ${ }^{116}$

Commentators note that, based on the language contained in section 3 , Congress likely intended section 5 of the Act of 1819 to supersede section 8 of the Act of $1790 ;{ }^{117}$ moreover, section 3 of the Act of 1820 was likely intended to supersede section 5 of the Act of $1819 .{ }^{118}$ Oddly, section 8 of the Act of 1790, section 5 of the Act of 1819, as well as section 3 of the Act of 1820, were reenacted in the Revised Statutes of $1874 .{ }^{119}$

\section{18 U.S.C. $\S \S 1651$ and 2: The Modern Piracy Statutes}

Final changes to the US definition of piracy occurred in 1909 in the Federal Criminal Code. ${ }^{120}$ The 1909 Federal Criminal Code was "[a]n [a]ct: To codify, revise, and amend the penal laws of the United States." ${ }^{121}$ It repealed section 8 of the Act of 1790 and established the definition provided in section 5 of the Act of $1819 .{ }^{122}$ Currently, the law from 1909 is

116. RUBIN, supra note 82 , at 381.

117. Dickinson, supra note 81, at 349.

118. Dickinson, supra note 81 , at 349.

119. Dickinson, supra note 81 , at 349.

120. See Dickinson, supra note 81 , at 349 (discussing the changes made to the federal criminal code of 1909).

121. Act of March 4, 1909, § 290, 35 Stat. 1145 (alterations added).

122. Id. 
codified as 18 U.S.C. $\S 1651 .{ }^{123}$ It provides in full that " $[\mathrm{w}]$ hoever, on the high seas, commits the crime of piracy as defined by the law of nations, and is afterwards brought into or found in the United States, shall be imprisoned for life." ${ }^{\prime 24}$ Consequently, 18 U.S.C. $\S 1651$ exports the definition of piracy to the "law of nations" definition.

Finally, 18 U.S.C. $\S 2$ provides the following:

(a) Whoever commits an offense against the United States or aids, abets, counsels, commands, induces or procures its commission, is punishable as a principal.

(b) Whoever willfully causes an act to be done which if directly performed by him or another would be an offense against the United States, is punishable as a principal. ${ }^{125}$

The combination of 18 U.S.C. $\S 2$ and 18 U.S.C. $\S 1651$ provides the federal statutory basis for charging pirate negotiators and facilitators as principals.

\section{The Early US Piracy Cases}

\section{United States v. Palmer}

The US Supreme Court first interpreted a congressional enactment of a piracy provision in United States v. Palmer. ${ }^{126}$ In Palmer the Supreme Court interpreted the Act of 1790 and consequently delineated, for the first time, the meets and bounds of piracy under congressional enactment. ${ }^{127}$ The issues before the Palmer Court were twofold: first, the Court had to decide whether Congress intended for actions that would constitute robbery on land, but were committed on the high seas, to be considered piracy. ${ }^{128}$ Second, the Court decided whether section 8 of the Act of 1790, which labeled as piracy "robbery" and "murder" committed by "any person or persons" on the high seas, could be considered piracy when it was applied to a non-US citizen on the high seas on a vessel belonging to the subject of a foreign State. ${ }^{129}$

In essence, the Palmer Court came to two conclusions regarding the Act of 1790. Regarding the first issue: piracy was the act of robbery, as

123. See Dickinson, supra note 81 , at 349 (discussing the changes made to the federal criminal code of 1909.).

124. 18 U.S.C. $\S 1651$ (1948).

125. 18 U.S.C. $\S 2$ (1951).

126. United States v. Palmer, 16 U.S. 610, 627 (1818).

127. See generally id.; see also Dickinson, supra note 81 , at 344.

128. Palmer, 16 U.S. at 627.

129. Id. at 632-33. 
recognized and defined by common law, committed on the high seas. ${ }^{130}$ In response to the second issue, the Court found that the crime of robbery by a non-US citizen committed on the high seas on board a vessel owned by a subject of a foreign State was not considered piracy under the Act of 1790 and, therefore, was not subject to punishment in US courts. ${ }^{131}$ In other words, because the Act of 1790 had not criminalized piracy as an offense against international law, the United States could not invoke universal jurisdiction to prosecute the foreign nationals under section 8 of its municipal statute. ${ }^{132}$ Ultimately, the deficiencies of the Act of 1790 laid the foundation for the Act of 1819 and eventually a decision by the Supreme Court in United States v. Smith.

\section{United States v. Smith}

In 1820, the US Supreme Court decided United States v. Smith; the Court considered the Act of 1819 to determine whether "plunder and robbery" constituted piracy by the law of nations, punishable under section 5 of the Act of $1819 .{ }^{133}$ The defendant in Smith had confined the officer of a ship commissioned by the government of Buenos Aires while in port, and then robbed the vessel while on the high seas. ${ }^{134}$ The defendant was captured and charged with piracy under section 5 of the Act of $1819 .{ }^{135}$ Consequently, the issue before the Court was whether section 5, relying on the "law of nations" for a definition of piracy, was a proper exercise of congressional authority under the "define and punish" clause of the Constitution. ${ }^{136}$

Unlike the piracy proscription contained in the Act of 1790, the piracy proscription in the Act of 1819 criminalized piracy through specific reference to the "law of nations." 137 Therefore, the Court held that an act punishing "the crime of piracy, as defined by the law of nations," was within Congress's constitutional authority to "define and punish" since it adopted by reference the sufficiently precise definition of piracy under international law: the act of "robbery upon the sea."138 In other words, Justice Story reasoned that the explicit reference to the law of nations was tantamount to listing the elements of piracy clearly within the statute. ${ }^{139}$

130. Id. at 629 .

131. MASON, supra note 109.

132. See Palmer, 16 U.S. 610, at 633-34.

133. United States v. Smith, 18 U.S. 153, 155 (1820).

134. Id. at 154 .

135. Id. at 155 .

136. Id. at 158 .

137. Act of 1819, ch. 77, § 5, 3 Stat. 510.

138. MASON, supra note 109 , at 3.

139. Smith, 18 U.S. at 159-60. 
Next, the Court considered what crimes constituted piracy under the "law of nations." "140 It considered three sources to determine how the law of nations defined piracy. The Court considered "the works of jurists, . . . the general usage and practice of nations ...., [and] . . . judicial decisions recgonising and enforcing [the law of nations on piracy]." concluded that there was sufficient agreement that "robbery, or forcible depredations upon the seas, animo furandi, is piracy;" therefore, it concluded that the reference to the law of nations in section 5 of the Act of 1819 was proper. ${ }^{142}$

\section{THE CUSTOMARY INTERNATIONAL LAW DEFINITION OF PIRACY: THE INTERNATIONAL FRAMEWORK GOVERNING PIRACY}

Commentators generally agree that the definition of piracy under the "law of nations" is found in UNCLOS. ${ }^{143}$ This Note addresses two main reasons for this conclusion. First, the UNCLOS definition embodied in article 101 has gained wide acceptance by the international community. Second, recent US case law corroborates the view that UNCLOS article 101 provides the law of nations definition of piracy.

The international community appears to have accepted the UNCLOS article 101 definition of piracy. ${ }^{144}$ In 2011 the United States drafted UN Resolution 2020, which reaffirmed that UNCLOS sets forth the legal framework for prosecuting piracy and armed robbery at sea as well as regulating other ocean activities. ${ }^{145}$ Resolution 2020, therefore, provides strong evidence that the international community relies on UNCLOS article 101 for the current international definition of piracy. ${ }^{146}$

Second, US case law seems to endorse US acceptance of the piracy definition set forth in UNCLOS, as well as the High Seas Convention before it. ${ }^{147}$ In the 2012 decision of United States v. Dire, the US Fourth Circuit Court of Appeals endorsed the conclusion provided by the US District Court for the Eastern District of Virginia in United States v. Hasan, that "the definition of general piracy under modern customary international

140. Id. at $160-62$.

141. United States v. Hasan, 747 F. Supp. 2d 599, 616 (E.D. Va. 2010), aff'd sub nom. United States v. Dire, 680 F.3d 446 (4th Cir. 2012) (quoting Smith, 18 U.S. at 160-61).

142. Hasan, 747 F. Supp. 2d at 616 (quoting Smith, 18 U.S. at 162).

143. Yvonne M. Dutton, Maritime Piracy and the Impunity Gap: Insufficient National Laws or a Lack of Political Will?, 86 TuL. L. REV. 1111, 1121 (2012) (citing Tullio Treves, Piracy, Law of the Sea, and Use of Force: Developments Off the Coast of Somalia, 20 EuR. J. INT'L L. 399, 401 (2009)).

144. S.C. Res. 2020, supra note 36, ๆ 7; see also United States v. Dire, 680 F.3d 446, 469 (4th Cir. 2012) (noting the "utmost significance" of the Resolution of 2020).

145. S.C. Res. 2020, supra note 36.

146. Dire, 680 F.3d at 469.

147. Id. at 468 . 
law is, at the very least, reflected in Article 15 of the 1958 High Seas Convention and Article 101 of the 1982 UNCLOS."

In concluding that UNCLOS provides the current definition of piracy under the law of nations, the Dire court largely adopted the rationale from United States v. Hasan. ${ }^{149}$ In Hasan, the court noted that treaties could create legal obligations on the States that are parties to them. ${ }^{150}$ As the Hasan court put it, "a treaty will only constitute sufficient proof of a norm of customary international law if an overwhelming majority of states have ratified the treaty, and those states uniformly and consistently act in accordance with its principles." 151 The Hasan court, however, went on to state that "it is also important to understand that a treaty can either 'embod[y] or create[ ] a rule of customary international law,' and such a rule 'applies beyond the limited subject matter of the treaty and to nations that have not ratified it." 152

Considering the general acceptance of UNCLOS, the Hasan court concluded that UNCLOS's definition of piracy represented a "widely accepted norm." "I53 It reasoned that "[ $t$ ]he 161 states parties to UNCLOS represent the 'overwhelming majority' of the 192 Member States of the United Nations, and the 194 countries recognized by the United States Department of State." 154 The United States did not pursue ratification of UNCLOS in the 1980s or 1990s based on concerns about the deep seabed mining provisions. ${ }^{155}$ However, it is not dispositive for the US's determination of "piracy" that the United States has not signed or ratified UNCLOS because the United States has acceded to the provisions regarding "traditional uses" of the ocean. ${ }^{156}$ Indeed, in a transmittal letter, President Bill Clinton addressed the US Senate stating that "Articles 100107 reaffirm the rights and obligations of all states to suppress piracy on the high seas;" he also emphasized that Congress had exercised its constitutional power to criminalize piracy through Section 1651..$^{157}$ Consequently, both international agreement and US case law interpreting international consensus appear in harmony that UNCLOS article 101 provides the current law of nations definition of piracy for purposes of 18

148. Hasan, 747 F. Supp. 2d at 632-33, aff'd sub nom. Dire, 680 F.3d 446.

149. Dire, 680 F.3d at 461 (citing Hasan, 747 F. Supp. 2d at 633).

150. Hasan, 747 F. Supp. $2 \mathrm{~d}$ at 633.

151. Id. (emphasis added).

152. Id. at 633 (alterations added).

153. Id. at 634 .

154. Id. at 633-34.

155. See Restatement (Third) of the Foreign Relations Law of the United States $\S 103$ reporter's note 2 (1986).

156. Hasan, 747 F. Supp. $2 d$ at 634.

157. See U.S. Dept. of State, Dispatch Supplement, Law of the Sea Convention: LETTERS OF TRANSMitTAL AND SUBMitTAL AND COMMENTARY 18 (1995). 
U.S.C. $§ 1651 .^{158}$

\section{A. International Treaties: The Harvard Draft Convention, the Geneva Convention, and UNCLOS}

The current "law of nations" definition of piracy is contained in UNCLOS article $101 ;^{159}$ however, the textual lineage of UNCLOS dates back to the High Seas Convention, and even further to the Harvard Draft Convention on Piracy before that. ${ }^{160}$ Consequently, an overview of these predecessor statutes helps provide the necessary context for a discussion of the current piracy provisions contained in the text of UNCLOS article 101.

\section{Piracy Under the Harvard Research in International Law Draft Convention on Piracy}

Published in 1932, The Harvard Draft Convention was an effort to consider the international law of piracy in preparation for a major codification, and the creation of a special jurisdiction for sea piracy. ${ }^{161}$ Although not an international agreement itself, the Harvard Draft Convention anticipated future codification - thus, it was intended "as an aid to the attempts of the time to 'codify' the rules of international law as they ought to exist rather than as they could be shown to exist by an examination of theory and past practice." 162 To this end, article 2 provides that "[e]very state has jurisdiction to prevent piracy and to seize and punish persons and to seize and dispose of property because of piracy." ${ }^{\text {"163 }}$ Indeed, the very theme of the draft was to define the meets and bounds of the universal jurisdiction over pirates. ${ }^{164}$

The text of the Harvard Research Draft Convention sets forth a definition of piracy in article 3 :

158. UNCLOS art. 101 appears to be the readily accepted contemporary definition of piracy under the law of nations. See United States v. Ali, No. 11-0106, 2012 WL 2870263 (D.D.C. July 13, 2012), opinion vacated in part, No. 11-0106, 2012 WL 3024763 (D.D.C. July 25, 2012).

159. See discussion supra in Part III.

160. Shibin Brief, supra note 43, at 18; Jon Bellish, Breaking News from 1932: Pirate Facilitators Must Be Physically Present on the High Seas, Eur. J. InT'L. L: TALK! (Sept. 19, 2012), http://www.ejiltalk.org/breaking-news-from-1932-pirate-facilitators-must-bephysically-present-on-the-high-seas/\#more-5662, archived at http://perma.cc/EZS2-F3WJ.

161. Rubin, supra note 82, at 308; B.H. Dubner, The Law of International Sea PIRACY 103 (1980).

162. RUBIN, supra note 82, at 309.

163. J. Bingham et al., Harvard Research in International Law: Draft Convention on Piracy, 26 Am. J. InT'L L. SuPP. 739, 768 (1932) [hereinafter Harvard Research].

164. Id. at 756 . 
Piracy is any of the following acts, committed in a place not within the territorial jurisdiction of any state:

1. Any act of violence or of depredation committed with intent to rob, rape, wound, enslave, imprison or kill a person or with intent to steal or destroy property, for private ends without bona fide purpose of asserting a claim of right, provided that the act is connected with an attack on or from the sea or in or from the air. If the act is connected with an attack which starts from on board ship, either that ship or another ship which is involved must be a pirate ship or a ship without national character.

2. Any act of voluntary participation in the operation of a ship with knowledge of facts which make it a pirate ship.

3. Any act of instigation or of intentional facilitation of an act described in paragraph 1 or paragraph 2 of this article. ${ }^{165}$

Furthermore, article 6 limits jurisdiction to areas not within the territorial jurisdiction of a State by providing, "[i]n a place not within the territorial jurisdiction of another state, a state may seize a pirate ship or a ship taken by piracy and possessed by pirates, and things or persons on board." ${ }^{166}$ Based on article 1, territorial jurisdiction is "the jurisdiction of a state under international law over its land, its territorial waters and the air above its land and territorial waters. The term does not include the jurisdiction of a state over its ships outside its territory." hand, the "high seas" were defined as "that part of the seas which is not included in the territorial waters of any state." 168

\section{Piracy under the Geneva Convention on the High Seas}

Created in 1958, the Geneva Convention on the High Seas (the High Seas Convention) serves as the first prominent international treaty governing the crime of piracy. The United Nations General Assembly asked the International Law Commission to draft a document that could form the predicate for an international agreement on the law of the sea-the result was the High Seas Convention. ${ }^{169}$ The High Seas Convention appears to have been intended as a declarative authority on customary international law at the time of its inception. ${ }^{170}$ Today the High Seas Convention has a

165. Id. at 743 .

166. Id. at 744 .

167. Id. at 743 .

168. Id.

169. RUBIN, supra note 82, at 319.

170. The preamble seeks to "codify the rules of international law relating to the high 
total of sixty-three states as parties, including the United States, which ratified the treaty on April 12, $1961 .^{171}$ Article 15 of the High Seas Convention contains the definition of piracy; as will be discussed infra, its language is virtually identical to the definition of piracy contained in UNCLOS article 101.

Turning to the text of article 15 of the High Seas Convention, piracy consists of any of the following acts:

(1) Any illegal acts of violence, detention or any act of depredation, committed for private ends by the crew or the passengers of a private ship or a private aircraft, and directed:

(a) On the high seas, against another ship or aircraft, or against persons or property on board such ship or aircraft;

(b) Against a ship, aircraft, persons or property in a place outside the jurisdiction of any State;

(2) Any act of voluntary participation in the operation of a ship or of an aircraft with knowledge of facts making it a pirate ship or aircraft;

Any act of intentionally facilitating an act described in subparagraph 1 or subparagraph 2 of this article. ${ }^{172}$

Finally, article 19 clearly establishes universal jurisdiction over the crime of piracy. It provides:

On the high seas, or in any other place outside the jurisdiction of any state, every state may seize a pirate ship or aircraft, or a ship taken by piracy and under the control of pirates, and arrest the persons and seize the property on board. The courts of the state which carried out the seizure may decide upon the penalties to be imposed and may also determine the action to be taken with regard to the property, subject to the rights of third states acting in good faith. $^{173}$

Much of the language from UNCLOS unmistakably resembles the language from the High Seas Convention. ${ }^{174}$

\footnotetext{
seas." Geneva Convention on the High Seas, preamble, Apr. 29, 1958, 13 U.S.T. 2312, 450

U.N.T.S. 397 [hereinafter High Seas Convention], archived at http://perma.cc/UH9R-2A7Z.

171. $I d$.

172. Id. art. 15 .

173. Id. art. 19 .

174. See UNCLOS, supra note 58, art. 101.
} 


\section{The United Nations Convention on the Law of the Sea}

The third United Nations Conference on the Sea convened in 1973. Resulting from the Conference was UNCLOS, which was a multilateral treaty adopted in $1982 .{ }^{175}$ Currently, 166 states have ratified or acceded to the terms of UNCLOS. ${ }^{176}$ The United States, however, has neither signed nor ratified its terms. ${ }^{177}$ Article 101 provides the relevant definition of piracy which consists of any of the following acts:

(a) any illegal acts of violence or detention, or any act of depredation, committed for private ends by the crew or the passengers of a private ship or a private aircraft, and directed:

(i) on the high seas, against another ship or aircraft, or against persons or property on board such ship or aircraft;

(ii) against a ship, aircraft, persons or property in a place outside the jurisdiction of any State:

(b) any act of voluntary participation in the operation of a ship or of an aircraft with knowledge of facts making it a pirate ship or aircraft;

(c) any act of inciting or of intentionally facilitating an act described in subparagraph (a) or (b). ${ }^{178}$

Furthermore, article 105 of UNCLOS virtually replicates article 19 of the High Seas Convention and reaffirms the applicability of universal jurisdiction over the crime of piracy. ${ }^{179}$ Finally, a ship becomes a pirate ship under article 103 "if it is intended by the persons in dominant control to be used for the purpose of committing one of the acts referred to in article 101." 180

Based on the language of UNCLOS article 101, an act is piratical if the following four elements are proven: (a) a specified criminal "act" (b)

175. See UNCLOS, supra note 58, art. 101.

176. Division for Ocean Affairs and the Law of the Sea, Office of the Legal Affairs, Table Recapitulating the Status of the Convention and of the Related AgREEMENTS, AS OF 30 JAN. 2013 (2013), archived at http://perma.cc/82GL-CX72.

177. Id. at 8 .

178. UNCLOS, supra note 58, art. 101.

179. "On the high seas, or in any other place outside the jurisdiction of any State, every State may seize a pirate ship or aircraft, or a ship or aircraft taken by piracy and under the control of pirates, and arrest the persons and seize the property on board. The courts of the State which carried out the seizure may decide upon the penalties to be imposed, and may also determine the action to be taken with regard to the ships, aircraft or property, subject to the rights of third parties acting in good faith." UNCLOS, supra note 58, art. 105.

180. UNCLOS, supra note 58, art. 10. 
committed for private ends (c) on the high seas ${ }^{181}$ and (d) directed against another ship. ${ }^{182}$

\section{a. The "Act" Requirement}

First, piracy under UNCLOS article 101 requires the commission of some specific "act." Article 101 essentially creates three categories of acts that would satisfy this requirement. ${ }^{183}$ Subsection (a) defines as piracy "illegal acts of violence or detention, or any act of depredation." 184 Subsection (b) goes further to include "voluntary participation" or "operation" of a ship that is used to commit acts of piracy. ${ }^{185}$ Finally, subsection (c) would include as piracy "inciting" or "facilitating" acts of violence or detention against a ship. ${ }^{186}$ Also included within each category are the mere acts of preparation or attempts at the acts themselves. ${ }^{187}$

\section{b. Private Ends Requirement}

Second, an act must be "committed for private ends." 188 The text of UNCLOS does not expressly define "private ends" and it remains somewhat unclear what the "private ends" requirement actually mandates. ${ }^{189}$ Commentators have interpreted the ambiguity in two divergent ways. Some commentators have interpreted this requirement narrowly by arguing that the "private ends" requirement would only be met if the acts are not taken for political reasons. ${ }^{190}$ Other commentators have interpreted the "private ends" requirement to encompass a larger category of activity; these commentators suggest that that the "private ends" requirement would not be met only when a government expressly authorizes the acts. ${ }^{191}$ This

181. This element will be discussed in more detail in Part IV. However, it is important to note that the UNCLOS definition of piracy only includes acts that occur outside of a state's territorial jurisdiction which may extend twelve miles from its coastline. UNCLOS, supra note 58 , arts. 2-3.

182. Dutton, supra note 143 , at 1122 .

183. Dutton, supra note 143, at 1122.

184. UNCLOS, supra note 58, art. 101(a).

185. UNCLOS, supra note 58, art. 101(b).

186. UNCLOS, supra note 58, art. 101(c).

187. Dutton, supra note 143, at 1122.

188. UNCLOS, supra note 58, art. 101(a).

189. Dutton, supra note 143, at 1122.

190. Geiss \& Petrig, supra note 91, at 61 (citing Clyde H. Crockett, Toward a Revision of the International Law of Piracy, 26 DePaul L. ReV. 78, 80 (1976) ("Some authors maintain that the requirement simply excludes all acts committed for political reasons from the ambit of piracy.")).

191. Dutton, supra note 143, at 1122 (citing Michael Bahar, Attaining Optimal Deterrence at Sea: A Legal and Strategic Theory for Naval Anti-Piracy Operations, 40 VAND. J. TRANSNAT'L L. 1, 27-37 (2007)). 
second interpretation is broader because any act of violence that is not expressly sanctioned by a state would meet the "private ends" requirement if it had any political underpinning. ${ }^{192}$ Nevertheless, it is conceivable that in the future, pirates could argue that their actions are politically motivated; if courts interpret the "private ends" requirement narrowly, then it is possible that the "private ends" requirement could exculpate some pirates. ${ }^{193}$

\section{c. High Seas Requirement}

Third, piracy under article 101 must occur on the "high seas," or "in a place outside the jurisdiction of any State." 194 The "high seas" requirement, which is particularly relevant to this Note, is referenced in UNCLOS article 3. Article 3 provides, "[e]very State has the right to establish the breadth of its territorial sea up to a limit not exceeding 12 nautical miles, measured from baselines determined in accordance with this Convention." 195 Commentators agree that acts that fulfill all of the requirements contained in UNCLOS article 101, but that occur within a state's territorial jurisdiction are not considered piracy. ${ }^{196}$ The "high seas" requirement, as it relates to the prosecution of pirate negotiators, will be discussed in more detail infra in Part IV.

\section{d. Two Ships Requirement}

Finally, because article 101(a)(i) includes the language "against another ship" there is a requirement that, for a conviction under article 101, an act of piracy must occur between two ships. ${ }^{197}$ Although some commentators may disagree as to what the two ships requirement really means, there is a good body of scholarship indicating that piracy does not consist of "crew seizures, mutiny or passenger takeovers of one and the same vessel . . . ."198 Indeed, the two-ship requirement contained in UNCLOS article 101 appears to be one of the primary motivations for adopting the Convention for the Suppression of Unlawful Acts Against the

192. Geiss \& Petrig, supra note 91 , at 61.

193. GEISS \& PETRIG, supra note 91, at 61; see also Dutton, supra note 143, at 1124.

194. UNCLOS, supra note 58, art. 101(a)(i)-(ii).

195. UNCLOS, supra note 58, art. 3.

196. GEISS \& PETRIG, supra note 91, at 60; see also Dutton, supra note 143, at 1125.

197. UNCLOS, supra note 58, art. 101(a)(i).

198. GeISS \& Petrig, supra note 91, at 62; see also Dutton, supra note 143, at 1125 (citing, inter alia, Eugene Kontorovich, International Decisions, United States v. Shi, 103 AM. J. INT'L L. 734, 737 (2009) ("“S]tating that treaty language and the preparatory papers support a conclusion that the two ship requirement is meant to screen out mutiny or other internal disturbances by crew and passengers, whose acts would remain within the jurisdiction of the flag state to prosecute.") (alteration added)). 
Safety of Maritime Navigation (SUA Convention). ${ }^{199}$ The SUA Convention was adopted in reaction to acts of maritime terrorism that occurred entirely on board one ship - the Palestinian hijacking of the Italian cruise liner the Achille Lauro is the paradigm. ${ }^{200}$ Unlike UNCLOS article 101, which requires two ships, article 3 of the SUA Convention prohibits both acts of intentional seizure and control of a ship and acts of violence against persons on board the ship, as well as attempts to engage in those acts. ${ }^{201}$ Thus, while an offense under the SUA Convention may arise out of acts committed entirely on one ship, UNCLOS article 101 requires a showing that two or more ships have been involved. ${ }^{202}$

\section{ANALYSIS OF WHETHER THE ACT OF NEGOTIATING CONSTITUTES PIRACY UNDER THE "LAW OF NATIONS"}

As discussed supra in Part III, UNCLOS article 101 provides the current "law of nations" definition of piracy for purposes of 18 U.S.C. $\S$ 1651. Under UNCLOS article 101(a)-(b), "any illegal act of violence or detention," or "any act of voluntary participation in the operation of a ship" satisfies the "act" requirement for a crime of piracy under UNCLOS $101 .{ }^{203}$ Article 101(c) also includes "any act of inciting or of intentionally facilitating an act described in subparagraph (a) or (b)." ${ }^{, 04}$ The current US cases of United States v. Shibin and United States v. Ali help define the scope of the high seas requirement under article 101.

In both United States v. Shibin and United States v. Ali the "private ends" and the "two ships" requirements are not at issue. ${ }^{205}$ In Shibin there was no dispute that Mohammad Shibin did "incit[e]" or "intentionally facilitat[e]" acts of violence by negotiating ransom agreements. ${ }^{206}$ Assuming Ali also "intentionally facilitated" acts of violence, the only remaining issue, at least when looking at US law to help determine international law, concerns the scope of the "high seas" requirement contained in UNCLOS article 101. Specifically, whether piracy under

199. Geiss \& Petrig, supra note 91, at 62.

200. Malvina Halberstam, Terrorism on the High Seas: The Achille Lauro, Piracy and the Imo Convention on Maritime Safety, 82 AM. J. INT'L L. 269, 291 (1988).

201. Convention for the Suppression of Unlawful Acts Against the Safety of Maritime Navigation art. 3, Mar. 10, 1988, 27 I.L.M. 672, 1678 U.N.T.S. 222, archived at http://perma.cc/T8SL-BE7Y.

202. Id.; UNCLOS, supra note 58, art. 101(a)(1).

203. UNCLOS, supra note 58, art. 101(a)-(b).

204. UNCLOS, supra note 58, art. 101(c).

205. United States v. Shibin, No. 2:11CR33, 2012 WL 195012 (E.D. Va. Jan. 23, 2012); United States v. Ali, 870 F. Supp. 2d 10 (D.D.C. 2012).

206. The defendant, Shibin, confessed to his role in the hijacking of the M/V Marida Marguerite and the S/V Quest; furthermore, Judge Robert G. Doumar denied Shibin's motion to suppress these confessions. Shibin, 2012 WL 195012, at*3-5 (alterations added). 
UNCLOS article 101(c) requires that an individual facilitate piracy while on the high seas, or whether the law of nations definition of piracy extends to acts of facilitation that occur outside the "high seas," in a state's territorial waters, or even on dry land. Turning to cases before the US Court of Appeals that deal with pirate negotiators, the answer to this question seems settled for the time being. The United States can prosecute pirate negotiators, under a theory of universal jurisdiction-even if they never act on the high seas - so long as their acts facilitated acts of piracy that did occur on the high seas. ${ }^{207}$ One question remains, however: can the United States now prosecute all piracy facilitators - investors, kingpins, and those who offer political support? More to the point—should the United States prosecute these individuals?

\section{A. Current US Attempts to Prosecute Pirate Negotiators: The Factual Background and Procedural Posture of the Shibin and Ali Cases}

\section{United States v. Shibin}

\section{a. The Factual Basis for the Prosecution of Mohammad Shibin}

The United States prosecuted Mohammad Saaili Shibin for his involvement in two separate pirate attacks. ${ }^{208}$ The first incident occurred in May of 2010, when several Somali nationals - not including Shibin himself-attacked and seized the M/V Marida Marguerite, a German-owed vessel with a crew of nineteen Indians, two Bangladeshis, and one Ukrainian. ${ }^{209}$ After the initial attack, the Marguerite and its crew of twentytwo were led to an area just off the coast of Somalia and held captive from May to December $2010 .{ }^{210}$ During this time, Shibin allegedly came to the Marguerite and proceeded to negotiate a ransom with the ship's owners. ${ }^{211}$ Shibin successfully negotiated a ransom with the owners of the Marida Marguerite, and received approximately $\$ 30,000$ to $\$ 50,000$ in US currency for his services. ${ }^{212}$

The second event occurred on February 19, 2011, when several armed Somali nationals, not including Shibin himself, boarded the S/V Quest, a

207. See generally Ali, 885 F. Supp. $2 d$ at 21, opinion vacated in part, 885 F. Supp. $2 d 55$ (D.D.C. 2012), rev'd in part, 718 F.3d 929 (D.C. Cir. 2013), and aff'd in part, 718 F.3d 929 (D.C. Cir. 2013); United States v. Shibin, 722 F.3d 233 (4th Cir. 2013).

208. Shibin, 2012 WL 195012, at*1-2; see also Press Release, Fed. Bureau of Investigation, Somali Hostage Negotiator in $\mathrm{S} / \mathrm{V}$ Quest and $\mathrm{M} / \mathrm{V}$ Miranda Marguerite Piracies Sentenced to Multiple Life Sentences (Aug. 13, 2012), archived at http://perma.cc/WD79-BNQE.

209. Shibin, 2012 WL 195012, at *1.

210. Press Release, Fed. Bureau of Investigation, supra note 208.

211. Shibin, 2012 WL 195012, at *1.

212. Id.; see also Press Release, Fed. Bureau of Investigation, supra note 208. 
US-flagged vessel, took the four US citizens on board as hostages, and then headed toward Somalia. ${ }^{213}$ United States military personnel aboard the USS Sterett, a US vessel "located off the coast of Somalia, attempted to secure the release of the hostages through negotiations with several of the hostagetakers." ${ }^{214}$ On February 20, 2011, one of the conspirators aboard the Quest purportedly identified Shibin "as the person responsible for negotiating the return of the hostages upon the vessel's arrival in Somalia." 215 "On February 22, 2011, one of the individuals on board the Quest fired a rocket-propelled grenade at the USS Sterett;" then, before Navy Seals could board the vessel, the four hostages were shot and killed. ${ }^{216}$ On April 4, 2011, Shibin was taken into custody by foreign forces in Somalia; he was questioned by FBI agents and eventually transported to the United States. ${ }^{217}$

\section{b. Procedural History: Indictment, Piracy Counts, and Sentencing of Mohammad Shibin}

In a superseding indictment, dated August 17, 2011, Mohammad Shibin was indicted on fifteen counts for his role in the seizure of the Marida Marguerite and the Quest; the indictment included piracy under the law of nations in counts one and seven. ${ }^{218}$ On November 1, 2011, Shibin filed a motion to dismiss count one of the superseding indictment. ${ }^{219}$ Count one alleged that from in and around May 2010, to in and around January 2011, Shibin committed the crime of piracy as defined under the law of nations in violation of 18 U.S.C. $\S \S 1651$ and $2 .{ }^{220}$ Shibin alleged that, under the government's proposed facts, he was only contacted after the Marguerite was seized, and therefore, only actively participated after the substantive offense of piracy had been completed. ${ }^{221}$ In other words, Shibin alleged that because he was never personally present on the high seas he was not subject to liability under 18 U.S.C. $\S \S 1651$ and $2 .^{222}$

Turning to the law of nations definition of piracy at the time of the offense, the government argued that both the 1958 High Seas Convention and the 1982 UNCLOS provide the law of nations definition of piracy; furthermore, both treaties define piracy to include the conduct charged in

\footnotetext{
213. Shibin, 2012 WL 195012, at *1.

214. Id.

215. Id.

216. Id.; see also Press Release, Fed. Bureau of Investigation, supra note 208.

217. Shibin, 2012 WL 195012, at $* 2$.

218. United States v. Shibin, No. 2:11CR00033, 2011 WL 3621858 (E.D. Va. Aug. 17,

219. United States v. Shibin, No. 2:11CR33, 2011 WL 9522735 (E.D. Va. Nov. 1, 2011).

220. Shibin, 2011 WL 3621858.

221. Shibin, 2011 WL 9522735.

222. Id.
} 2011). 
Shibin's case. ${ }^{223}$ In particular, the government alleged that under section (3) of the High Seas Convention, and UNCLOS article 101(c), Shibin facilitated acts of violence and detention when he provided negotiation services. ${ }^{224}$ In essence, the government alleged that Shibin was a link in the "causal chain" between the physical acts of piracy and the ultimate ransom delivery. ${ }^{225}$ More important, for the purposes of this Note, the government argued that the facilitation prong of the piracy definition contained in the High Seas Convention could be satisfied by acts occurring within a State's territorial jurisdiction. ${ }^{226}$

Judge Robert Doumar allowed Shibin's case to proceed on all counts, and even ruled against Shibin on motion to suppress statements made while in custody. ${ }^{227}$ In April of 2012, a jury convicted Shibin of all fifteen counts contained in the superseding indictment. ${ }^{228}$ Subsequently, he was sentenced to ten concurrent and two consecutive life sentences. ${ }^{229}$ On December 13, 2012, Shibin filed an appellate brief with the Fourth Circuit Court of Appeals challenging the District Court's ruling on several pre-trial motions. ${ }^{230}$ In upholding Shibin's conviction, the Fourth Circuit held that "conduct violating Article 101(c) does not have to be carried out on the high seas, but it must incite or intentionally facilitate acts committed against ships, persons, and property on the high seas." ${ }^{, 31}$

\section{United States v. Ali}

\section{a. The Factual Background for the Prosecution of Ali Mohamed Ali}

The second case concerns charges filed against Ali Mohamed Ali. ${ }^{232}$ The charges stem from the hijacking of the M/V CEC Future, a Bahamianflagged cargo ship, owned by Clipper Group A/S, a Danish company. ${ }^{233}$ On November 7, 2008, the CEC Future was seized by Somali pirates as it was sailing in the Gulf of Aden, off the coast of Yemen. ${ }^{234}$ The pirates forced

\footnotetext{
223. Id.

224. Id.

225. $I d$.

226. Id.

227. Shibin, 2012 WL 195012, at*7.

228. Press Release, United States Attorney's Office E. Dist. of Va., Somali Hostage Negotiator In S/V Quest Piracy And Pirating Of M/V Marida Marguerite Found Guilty Of All Counts (Apr. 27, 2012) archived at http://perma.cc/U2M7-QWU6.

229. Press Release, Fed. Bureau of Investigation, supra note 208.

230. Shibin Brief, supra note 43, at 10-11.

231. United States v. Shibin, 722 F.3d 233, 241 (4th Cir. 2013).

232. United States v. Ali, 870 F. Supp. 2d 10, 15 (D.D.C. 2012).

233. Id.

234. Id.
} 
the ship to Point Raas Binna, near the Somali coast. ${ }^{235}$ On or about November 9 or 10, Ali boarded the ship before it sailed to waters near Eyl, Somalia, and allegedly communicated ransom demands from the pirates to Clipper Group. ${ }^{236}$ "Initially, Ali communicated with 'Steven,' a negotiator hired by Clipper [Group], but as the incident wore on, Ali began communicating directly with Per Gullestrup, Clipper's CEO."237

The government further alleges that Ali negotiated a ransom of $\$ 1.7$ million for the release of the ship, and that he also negotiated a separate payment of $\$ 75,000$ for himself. ${ }^{238}$ "On January 16, 2009, after Clipper Group paid the $\$ 1.7$ million, Ali and the pirates disembarked the ship. Ali allegedly received the $\$ 75,000$ from Clipper on or about January 27, 2009."239

In June of 2010, Ali was appointed the Director General of the Ministry of Education in Somaliland, a self-declared republic within Somalia. ${ }^{240}$ Then, in March of 2011, Ali received an email from a US foundation inviting him to attend a conference on education in Raleigh, North Carolina. ${ }^{241}$ Ali traveled to the United States and was arrested when he arrived at Dulles International Airport on April 20, 2011. ${ }^{242}$

\section{b. Procedural History: Indictment, Piracy Charges, and Current Status of the Case Against Ali Mohamed Ali}

An indictment returned on April 15, and unsealed on April 21, 2011 charged Ali with

conspiracy to commit piracy under 18 U.S.C. $\S \S 1651,371$

(Count One); piracy and aiding and abetting under 18

U.S.C. $\S \S 1651,2$ (Count Two); conspiracy to commit hostage taking under 18 U.S.C. $\S 1203$ (Count Three); and hostage taking and aiding and abetting under 18 U.S.C. $\S \S$ 1203, 2 (Count Four). ${ }^{243}$

On May 29, 2012, Ali filed a motion to dismiss counts one through four of the indictment. ${ }^{244}$ In a memorandum opinion issued on July 13,

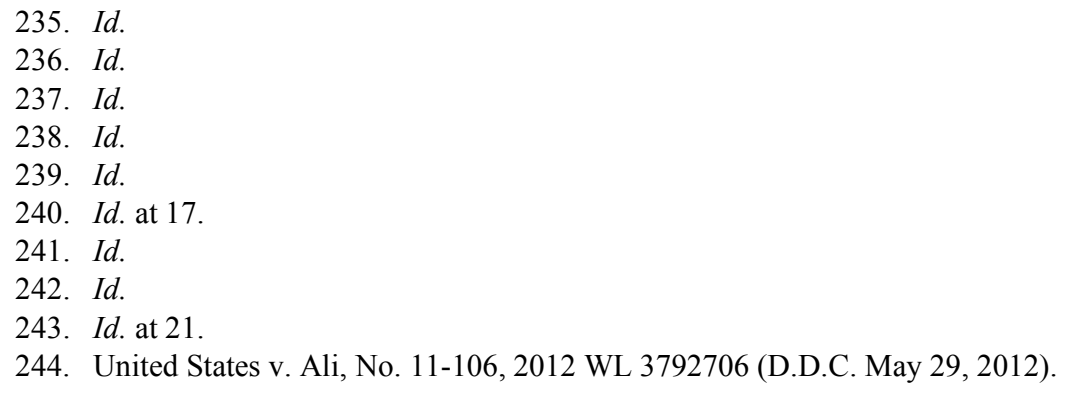


2012, District Court Judge Ellen Huvelle granted in part and denied in part Ali's motion. ${ }^{245}$ The court dismissed count one, conspiracy to commit piracy, for failure to state an offense because conspiracy was not in the UNCLOS definition. ${ }^{246}$ The court allowed count two, aiding and abetting, to proceed because it found that 18 U.S.C. $\S \S 1651$ and 2 were the functional equivalent of UNCLOS article 101(c). ${ }^{247}$ However, the Court narrowed the piracy and aiding and abetting offense of count two, concluding: "[i]t will be the government's burden to convince the jury beyond a reasonable doubt that Ali intentionally facilitated acts of piracy while he was on the high seas. ${ }^{248}$ It denied Ali's motion in all other respects. ${ }^{249}$

At the outset of the case it seemed a foregone conclusion that the government would be able to show that Ali facilitated piracy while on the high seas. Initially, on June 11, 2012, the government stated: "the evidence will show that [Ali] was acting as a negotiator for the pirates while the $C E C$ Future was on the high seas." ${ }^{250}$ However, at a status hearing conducted July 20, 2012, the government had revised its position, contending instead that "Ali boarded the CEC Future on November 9, 2008, in territorial waters, and that the $C E C$ Future then sailed through international waters for a matter of 'minutes'. . . before stopping in Somali waters near Eyl, where it

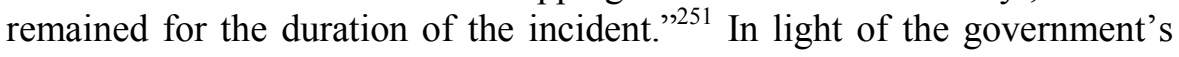
change in position, District Court Judge Ellen Huevelle stated that she was misled by a government claim that Ali was in international waters. ${ }^{252}$ In fact, Judge Huevelle went further to call the prosecution's dramatic change in position "unbelievably inexcusable behavior." 253

In a memorandum opinion issued after the status hearing on July 20, Judge Huevelle vacated Section II(D) of the July 13 opinion and dismissed courts three and four. ${ }^{254}$ Moreover, she released Ali Mohamed Ali from prison and allowed him to be confined at a friend's home in Centerville, Virginia, while the government appealed several of the pretrial rulings. ${ }^{255}$

245. Ali, 885 F. Supp. $2 d$ at 45.

246. Id. at 35; see also FED. R. CRIM. P. 12(b)(3)(B).

247. Ali, 885 F. Supp. 2 d at 32.

248. Id.

249. Id. at $45-46$.

250. Id. at 57 .

251. Id.

252. Ali, 885 F. Supp. 2d at 57-58; see also Martha Neil, Federal Judge Blasts US Prosecutors for 'Unbelievably Inexcusable Behavior' in Somali Piracy Case, ABA JouRnAL (July 23, 2012, 5:11 PM), http://www.abajournal.com/news/article/federal_judge_blasts_prosecution_in_somali_piracy _case_for_unbelievably_ine/, archived at http://perma.cc/LL88-KCY8.

253. Neil, supra note 252.

254. Ali, 885 F. Supp. 2 d at 62.

255. Frederic J. Frommer, Alleged Somali Pirate Ordered Back Into Custody, Associated Press (Aug. 3, 2012, 9:06 PM), http://bigstory.ap.org/article/alleged-somali- 
The government filed an emergency motion with the US Court of Appeals for the District of Columbia Circuit seeking an immediate stay of the district court's release order, and an order returning Ali to custody pending an appeal of the District Court's release order. ${ }^{256}$ The D.C. Circuit Court of Appeals granted the government's motion, and, without issuing an opinion, instructed Judge Huvelle to return Ali to custody pending trial. ${ }^{257}$ Judge Huvelle issued the order and Ali was returned to custody by the Department of Corrections. ${ }^{258}$

Most recently, the Court of Appeals for the District of Columbia Circuit ruled on an appeal by the US Government regarding Judge Huvelle's decision to dismiss, in part, charges of aiding and abetting piracy. It held that the prosecution of someone for the crime of aiding and abetting piracy, based on acts not committed on the high seas, was consistent with the law of nations. ${ }^{259}$

B. The Text of UNCLOS, the Legislative History of 18 U.S.C. $\$ \S 1651$ and 2, and Consideration of International Law: A Comparative Analysis of the Arguments Presented in U.S. v. Shibin and U.S. v. Ali

Those wishing to impose a "high seas" requirement (supporters of the high seas requirement), including Mohammad Shibin, ${ }^{260}$ have made several arguments suggesting that the government should be required to prove beyond a reasonable doubt that an individual facilitated piracy while on the high seas to procure a conviction under 18 U.S.C. $\S \S 1651$ and 2. On the other hand, those who oppose requiring the government to satisfy a "high seas" requirement (opponents of the high seas requirement), such as the US Government, suggest that 18 U.S.C. $\S \S 1651$ and 2 can apply to conduct that occurs beyond the high seas because UNCLOS article 101(c) does not explicitly mention the "high seas." Both sides of the debate have supported their respective positions with a combination of arguments focusing on the text of UNCLOS article 101, legislative history, and general principles of international law. ${ }^{261}$ Ultimately, at the US appellate level, the law has been settled with respect to pirate negotiators: the US Government does not need to prove that negotiators facilitated piracy while on the high seas, even when universal jurisdiction is the theory used to prosecute the negotiator.

pirate-ordered-back-custody, archived at http://perma.cc/3CW8-DS3T.

256. Emergency Motion for Order Staying District Court's Order of Release and for Issuance of Writ to Return Defendant to Custody of United States Marshals Service or, in the Alternative, for Expedited Briefing of the Government's Appeal of the District Court's Order of Release at 1, Ali, 885 F. Supp. 2d 55 (No. 12-3056), archived at http://perma.cc/Q62Q-ZXMK.

257. Frommer, supra note 255.

258. Frommer, supra note 255.

259. United States v. Ali, 718 F.3d 929, 936 (D.C. Cir. 2013).

260. See Shibin Brief, supra note 43, at 12.

261. See Ali, 885 F. Supp. 2d at 30; see also id. at 24-28. 


\section{The Text of UNCLOS Article 101}

The strongest argument for opponents of the "high seas" requirement focuses on a plain language comparison between the text of UNCLOS article 101(a) and the text of article 101(c) ${ }^{262}$ Article 101(a) designates as piracy "illegal acts of violence or detention ... committed for private ends by the crew or passengers of a private ship or a private aircraft, and directed: (i) on the high seas . ... ${ }^{263}$ On the other hand, UNCLOS article 101(c) defines piracy as "any act of inciting or of intentionally facilitating an act described in subparagraph (a) or (b)." ${ }^{264}$ Article 101(a) specifically includes "high seas" language, but article 101(c) excludes such "high seas" language. ${ }^{265}$ Opponents of a high seas requirement argue that if a high seas requirement were imputed to article 101(c), then the "high seas" language contained in the first definition of piracy would be rendered ineffectual. ${ }^{266}$ Because statutory construction mandates an interpretation that ensures that statutory language is not rendered meaningless, then the lack of a high seas requirement in article 101(c) must be interpreted as an intentional omission. ${ }^{267}$

Absence of "high seas" language in article 101(c) is strong evidence that acts of pirate facilitation can occur outside of the high seas. As the Court of Appeals for the District of Columbia Circuit put it, "[e]xplicit geographical limits - 'on the high seas' and 'outside the jurisdiction of any state'-govern piratical acts under article 101(a)(i) and (ii). Such language is absent, however, in article 101(c), strongly suggesting a facilitative act need not occur on the high seas so long as its predicate offense has. $" 268$ Likewise, the Fourth Circuit Court of Appeals interpreted article 101(a) and article 101(c) as creating separate offenses:

262. See Geiss \& Petrig, supra note 91, at 64-65; Government's Response to Defendant's Motion to Dismiss All Charges for Lack of Jurisdiction, United States v. Shibin, No. 2:11CR33, 2011 WL 9522720 (E.D. Va. Nov. 15, 2011) [hereinafter Government's Response, Shibin]; Douglas Guilfoyle, Committing Piracy on Dry Land: Liability for Facilitating Piracy, EJIL: TALK! (July 26, 2012), http://www.ejiltalk.org/committing-piracyon-dry-land-liability-for-facilitating-piracy/, archived at http://perma.cc/PF8J-B9QB; Roger L. Phillips, Intentional Facilitation and Commission of Piracy as Part of a Joint Criminal Enterprise, Communis Hostis OMNium (July 26, 2012), http://piracylaw.com/2012/07/26/intentional-facilitation-and-commission-of-piracy-as-part-of-a-jointcriminal-enterprise/, archived at http://perma.cc/A3JC-ZRSX; Bellish, supra note 54.

263. UNCLOS, supra note 58, art. 101(a).

264. UNCLOS, supra note 58, art. 101(c).

265. UNCLOS, supra note 58, art. 101.

266. See Government's Response, Shibin, supra note 262; Guilfoyle, supra note 262; Phillips, supra note 262; Bellish, supra note 54.

267. See Government's Response, Shibin, supra note 262; Guilfoyle, supra note 262; Phillips, supra note 262; Bellish, supra note 54.

268. United States v. Ali, 718 F.3d 929, 937 (D.C. Cir. 2013). 
The text of Article 101 describes one class of acts involving violence, detention, and depredation of ships on the high seas and another class of acts that facilitate those acts. In this way, Article 101 reaches all the piratical conduct, wherever carried out, so long as the acts specified in Article 101(a) are carried out on the high seas. ${ }^{269}$

Scholars who argue that article 101(c) does implicitly contain a high seas requirement counter with a textual argument considering the text of UNCLOS in its entirety. ${ }^{270}$ For example, article 86 provides that the provisions contained in Part VII on the High Seas-the part that contains the article 101 definition of piracy - "apply to all parts of the sea that are not included in the exclusive economic zone, in the territorial sea or in the internal waters of a State, or in the archipelagic waters of an archipelagic State." ${ }^{271}$ Article 86 further provides: "[ $t$ ]his article does not entail any abridgment of the freedoms enjoyed by all States in the exclusive economic zone in accordance with article 58. ${ }^{272}$ Both the Court of Appeals for the District of Columbia and the Fourth Circuit rejected this argument largely because reading a high seas requirement into article 101(c) would result in numerous redundancies throughout UNCLOS. ${ }^{273}$ A better reading of article 86, according to the US appellate courts, interprets the article in an introductory, or definitional role, for the portions of UNCLOS dealing with issues pertaining to the high seas. ${ }^{274}$

Likewise, article 100 provides a duty to cooperate in the repression of piracy, but includes an explicit high seas requirement: "states shall cooperate to the fullest possible extent in the repression of piracy on the high seas . ..."275 Article 105 makes a similar reference to the "high seas." It provides: "[o]n the high seas, or in any other place outside the jurisdiction of any State, every State may seize a pirate ship . . . taken by piracy and under the control of pirates, and arrest the persons and seize the property on board." ${ }^{276}$ Based on the explicit high seas requirement found in articles 86 , 100 , and 105, supporters argue that a high seas requirement should be imputed to UNCLOS article 101(c) as a prerequisite for any exercise of universal jurisdiction. ${ }^{277}$ The Court of Appeals for the District of Columbia

269. United States v. Shibin, 722 F.3d 233, 241 (4th Cir. 2013).

270. See Bellish, supra note 54.

271. UNCLOS, supra note 58, art. 86.

272. UNCLOS, supra note 58, art. 86.

273. Ali, 718 F.3d at 937; Shibin, 722 F.3d at 241.

274. Ali, 718 F.3d at 938; Shibin, 722 F.3d at 241.

275. UNCLOS, supra note 58, art. 100.

276. UNCLOS, supra note 58, art. 105.

277. Government's Response, Shibin, supra note 262; see also Bellish, supra note 54 (discussing the views of proponents of the high seas requirement). 
again rejected this argument, reasoning that article 105's reference to the "high seas highlights the broad authority of nations to apprehend pirates even in international waters." 278

Considering the text of UNCLOS article 101(c), in juxtaposition to the text of article 101(a), it appears as though no high seas requirement exists for those individuals who merely "incite" or "intentional[ly] facilitate" acts of piracy. ${ }^{279}$ Indeed, a plain language reading of the text of UNCLOS article 101 was dispositive for the Fourth Circuit, and the D.C. Circuit Courts of Appeals. ${ }^{280}$

\section{Legislative History: 18 U.S.C. $\$ 2$ and the Charming Betsy Cannon}

Supporters of the high seas requirement argue that Congress did not intend for $\S 2$ to apply to acts of general piracy. Indeed, the district court in U.S. v. Ali analyzed the legislative history behind 18 U.S.C. $\S 2$ to suggest that Congress did not intend for $\S 2$ to broaden the scope of 18 U.S.C. $\S$ 1651 to include facilitation in foreign territorial waters. ${ }^{281}$ This line of argument supports the position held by those wishing to impose a high seas requirement because it favors a narrower reading of 18 U.S.C. $\S \S 1651$ and 2.

Supporters of the high seas requirement reason that both 18 U.S.C. $\S$ 1651 and 18 U.S.C. $\S 2$ have their origin in the Crimes Act of 1790; $\$ 1651$ originates from section 8 and $\S 2$ originates from section 10 of that Act respectively. ${ }^{282}$ In 1818, the Supreme Court in United States v. Palmer reasoned that the piracy provisions contained in the Crimes Act of $1790 \mathrm{did}$ not include the acts of foreigners aboard foreign vessels traversing the high seas. ${ }^{283}$ In particular, the Court analyzed section 10 which, by its language, purported to apply to "any person":

It will scarcely be denied that the words "any person," when applied to aiding or advising a fact, are as extensive as the same words when applied to the commission of that fact. Can it be believed that the legislature intended to punish with death the subject of a foreign prince, who, within the dominions of that prince, should advise a person,

278. Ali, 718 F.3d at 938 .

279. GEISS \& PETRIG, supra note 91, at 64-65.

280. See Ali, 718 F.3d at 937; United States v. Shibin, 722 F.3d 233, 241 (4th Cir. 2013).

281. United States v. Ali, 885 F. Supp. 2d 17, 21 (D.D.C. 2012), opinion vacated in part, 885 F. Supp. 2d 55 (D.D.C. 2012), rev'd in part, 718 F.3d 929 (D.C. Cir. 2013), and aff'd in part, 718 F.3d 929 (D.C. Cir. 2013).

282. Id.

283. Id.; Shibin Brief, supra note 43, at 21 (citing United States v. Palmer, 16 U.S. 610, 633-34 (1818)). 
about to sail in the ship of his sovereign, to commit murder or robbery ${ }^{284}$

Subsequently, Congress passed the Act of March 3, 1819, which criminalized not only piratical acts with a nexus to the United States, but also piracy as an international offense subject to universal jurisdiction. ${ }^{285}$ Supporters of the high seas requirement note that while Congress revised section 8 to include general piracy, Congress did not revise section 10; therefore, Congress did not revise the Palmer Court's holding that section 10 applied as a municipal statute. ${ }^{286}$ Because Congress had the opportunity to revise section 10 - which is $\S 2$ 's predecessor-in the Act of 1819 , but chose not to, it stands to reason that Congress does not intend for the modern $\S 2$ to apply to general piracy. ${ }^{287}$

The Charming Betsy cannon presumes that Congress does not intend to violate international law, so that an ambiguous statute must be construed so that it does not violate the "law of nations." 288 When universal jurisdiction is the basis for a court's jurisdiction over a particular matter, the court must determine whether the charged conduct falls within the international law definition of a universal jurisdiction crime; otherwise it would violate international law, and consequently the Charming Betsy cannon as well. ${ }^{289}$ As discussed supra in Part III, UNCLOS article 101 provides the international law definition of piracy. ${ }^{290}$ UNCLOS provides that 'any act of inciting or of intentionally facilitating" an act of piracy is itself piracy' as defined by UNCLOS Article 101(c)." "291 Furthermore, "[u]nder domestic law, 18 U.S.C. $\S 2$ makes those who aid, abet, counsel, command, induce, procure, or willfully cause the commission of a federal crime punishable as a principle." ${ }^{292}$ The court in Ali reasoned that the aiding and abetting charge in count two was functionally equivalent to the definition contained in UNCLOS article 101(c); therefore, it permitted the charge to proceed. ${ }^{293}$ However, because of the Charming Betsy cannon, the Ali court reasoned that the government must prove "that Ali intentionally facilitated acts of piracy while he was on the high seas." 294

284. Ali, 885 F. Supp. 2 d at 31 (citing Palmer, 16 U.S. at 633).

285. Id.; see Act of 1819, ch. 77, § 5, 3 Stat. 513-14.

286. Ali, 885 F. Supp. 2d at 31; Shibin Brief, supra note 43, at 21.

287. Ali, 885 F. Supp. 2d 17; Shibin Brief, supra note 43, at 21.

288. Ali, 885 F. Supp. 2d at 32 (citing George E. Warren Corp. v. EPA, 159 F.3d 616, 624 (D.C. Cir. 1998) (some internal quotation marks omitted) (quoting S. African Airways v. Dole, 817 F.2d 119, 125 (D.C. Cir. 1987))).

289. Id. at 29 .

290. Id.; see supra Part III.

291. Ali, 885 F. Supp. 2 d at 30.

292. Id. (citing 18 U.S.C. $\S \S 2(a), 2(b))$.

293. Id. at 30 .

294. Id. at 29 . 
On the other hand, opponents of the high seas requirement, including the federal prosecutors in United States v. Shibin and the US Court of Appeals for the District of Columbia, reason that 18 U.S.C. $\S \S 1651$ and 2 apply extraterritorially by virtue of their plain meaning. ${ }^{295}$ Opponents of the "high seas" requirement argue that Congress intended 18 U.S.C. $§ 1651$ to apply extraterritorially because it defined piracy by reference to the "law of nations" which can evolve over time. ${ }^{296}$ The government has argued that, where Congress has expressed a clear intent for a criminal statue to apply extraterritorially, it is unnecessary for the courts to consider customary international law because Congress has the power to create legislation that violates international law. ${ }^{297}$ The government in Shibin argued that the acts of those pirates who physically act on the high seas are clearly prohibited by 18 U.S.C. $\S 1651$, through reference to UNCLOS article 101, while those who participate in the act of piracy are equally culpable under 18 U.S.C. $\S 2$ by reference to UNCLOS article 101(c). ${ }^{298}$ Opponents of the high seas requirement argue that US domestic jurisdiction is consistent with the universal jurisdiction under customary international law, and international law prohibits acts of facilitation. ${ }^{299}$ The D.C. Circuit Court of Appeals found this argument persuasive: "[b]ecause international law permits prosecuting acts of aiding and abetting piracy committed while not on the high seas, the Charming Betsy canon is no constraint on the scope of Count Two." $" 300$

\section{The Competing Interest of International Law: Expediency vs. The Requirements of Customary International Law Under UNCLOS article 101}

Another argument articulated by opponents of the high seas requirement centers on the practical benefits of prosecuting those who facilitate acts of piracy from Somali territorial waters. The necessity of stopping the scourge of piracy, the argument suggests, should weigh strongly in favor of not imposing a high seas requirement. ${ }^{301}$ In the Shibin case, for example, the US Government relied on practical arguments to come to the conclusion that UNCLOS should not include a "high seas" requirement:

295. United States v. Shibin, No. 2:11CR33, 2012 WL 8231152, at *5 (E.D. Va. Apr. 16, 2012), aff'd, 722 F.3d 233 (4th Cir. 2013) (citing United States v. Yousef, 327 F.3d 56, 9196 (2d Cir. 2003)); United States v. Ali, 718 F.3d 929, 936 (D.C. Cir. 2013).

296. Shibin, $2012 \mathrm{WL} 8231152$, at $* 5$.

297. Id.

298. $I d$.

299. Id.

300. United States v. Ali, 718 F.3d 929, 939 (D.C. Cir. 2013).

301. Government's Response, Shibin, supra note 262. 
This conclusion not only flows from the plain reading of UNCLOS, but also makes sense in practice. Any other rule would allow the persons who finance piracy in Somalia and the persons who negotiate for the pirates to act with impunity, orchestrating and enabling international crime without fear of facing justice in the courts of the nations whose citizens and ships they prey upon. ${ }^{302}$

Prosecuting negotiators and financiers may be one of the most promising ways of stopping global piracy. ${ }^{303}$ This argument has gained international attention: the United National Security Council has recognized the "need to investigate and prosecute not only suspects captured at sea, but also anyone who incites or intentionally facilitates piracy operations, including key figures of criminal networks involved in piracy who illicitly plan, organize, facilitate, or finance and profit from such attacks. $" 304$ Opponents of the high seas requirement have argued that public necessity favors prosecuting those who act from within territorial waters.

On the other hand, supporters of the high seas requirement have argued that an interpretation of UNCLOS article 101(c), which permits the US government to prosecute individuals for conduct occurring within a state's territorial jurisdiction, itself violates the traditional understanding of piracy law. ${ }^{305}$ Supporters of the high seas requirement have argued that the history behind the piracy provisions of UNCLOS indicates that UNCLOS article 101(c) does not reach into the territory of a sovereign state-even when the crime is one of facilitation. ${ }^{306}$ The language of UNCLOS comes from the 1958 High Seas Convention and the 1932 Harvard Research in International Law Draft Convention on Piracy. ${ }^{307}$ Article 3(3) of the Harvard Draft Convention on Piracy defines as piracy "[a]ny act of instigation or of intentional facilitation of an act described in paragraph 1 or paragraph 2 of this article." 308

The comments to article 3 elaborate on this definition, providing an indication of the drafter's intent. ${ }^{309}$ In particular, the note to article 3 ties acts of facilitation to the "high seas." $"$ Note 3 provides:

302. Government's Response, Shibin, supra note 262

303. Jon Bellish, Will the United States Play a Role in Prosecuting Pirate "Kingpins?", Communis Hostis OMnium (Apr. 21, 2012), http://piracy-law.com/2012/04/21/will-theunited-states-play-a-role-in-prosecuting-pirate-kingpins/, archived at http://perma.cc/3H8XEFKN.

304. S.C. Res. 2020, supra note 36.

305. Ali, 885 F. Supp. 2d at 32; see also Shibin Brief, supra note 43, at 16.

306. Shibin Brief, supra note 43 , at 16-18.

307. Shibin Brief, supra note 43, at 17-18.

308. Harvard Research, supra note 163, at 149; see also id. at 17-18.

309. Shibin Brief, supra note 43, at 18; Bellish, supra note 160.

310. Harvard Research, supra note 163, at 149. 
By this clause, instigations and facilitations of piratical acts, previously described in the Article are included in the definition of piracy. Obviously, convenience is served by this drafting device. The act of instigation or facilitation is not subjected to the common jurisdiction unless it takes place outside territorial jurisdiction. ${ }^{311}$

Commentators who support a "high seas" requirement have latched on to the language in note 3 to argue that the Harvard Draft Convention contemplated a high seas requirement for acts of facilitation and instigation. ${ }^{312}$

The text of UNCLOS article 101(c) can be traced back to the language of the Harvard Draft Convention; therefore, the Harvard Draft Convention provides a strong indication of how UNCLOS article 101(c) should be interpreted. ${ }^{313}$ The 1956 Draft Articles on the Law of Sea, which formed the basis for the High Seas Convention, endorsed the 1932 Harvard Draft Convention on Piracy. ${ }^{314}$ Finally, UNCLOS adopted virtually the same definition of piracy as was contained in the High Seas Convention. ${ }^{315}$ Therefore, because the language of UNCLOS article 101 can be traced back to the 1932 Harvard Draft Convention on Piracy, and because that Convention specified a high seas requirement for facilitation, then it stands to reason that UNCLOS article 101(c) also contains a high seas requirement for facilitation.

This argument has found little favor at the federal appellate level in the United States, when the D.C. Court of Appeals considered relying on the Harvard Draft Convention "a bridge too far." 316 The D.C. Circuit reasoned that deducing a single intent from the legislative history of UNCLOS would prove difficult. ${ }^{317}$ Moreover, it reasoned that basic principles of statutory interpretation allow courts to consider extraneous materials only when the plain language of the treaty is unclear. ${ }^{318}$ Based on the foregoing discussion, the D.C. Circuit found the plain language of

311. Harvard Research, supra note 163, at 149; see also Shibin Brief, supra note 43, at 18.

312. Shibin Brief, supra note 43, at 18; Bellish, supra note 160.

313. Bellish, supra note 160.

314. "In its work on the articles concerning piracy, the Commission was greatly assisted by the research carried out at the Harvard Law School, which culminated in a draft convention of nineteen articles with commentary, prepared in 1932 under the direction of Professor Joseph Bingham. In general, the Commission was able to endorse the findings of that research." Bellish, supra note 160; see also 1956 Y.B. OF THE ILC, Vol. II, at 282.

315. Compare High Seas Convention, supra note 170, art. 15, with UNCLOS, supra note 58, art. 101.

316. United States v. Ali, 718 F.3d 929, 939 (D.C. Cir. 2013).

317. Id.

318. Id. 
UNCLOS article 101 to be dispositive; it did not consider the legislative intent behind article 101 in its analysis. ${ }^{319}$

\section{RECOMMENDATIONS}

Given the background information regarding the history of piracy in the United States and under the "law of nations"-considering also recent US attempts to prosecute pirate negotiators - a normative question arises: what role, if any, should the United States play in prosecuting individuals who negotiate and facilitate acts of piracy from within Somali territorial jurisdiction, and on the Somali mainland? This question at once gives rise to at least three potential responses.

First, the United States could take an aggressive, pro-prosecution stance by indicting and prosecuting white-collar, high-ranking pirates and those who facilitate acts of piracy. Based on the holdings in United States $v$. Shibin and United States v. Ali, it seems clear that the United States has strong legal ground to stand on for prosecuting pirate negotiators. ${ }^{320}$ However, the United States could interpret Shibin and Ali as also providing the legal basis for prosecuting all those individuals who "incit[e] or intentionally facilitate[e]" 321 acts of piracy, regardless of their geographic location. In other words, federal prosecutors could begin prosecuting highranking Somali pirates: the kingpins, investors, and individuals who provide political capital to piracy operations. ${ }^{322}$ This pro-prosecution position follows from the broadest reading of United States v. Shibin and United States v. Ali.

Second, federal prosecutors could read the holdings in Shibin and Ali in a narrow manner as establishing the legal basis for prosecuting pirate negotiators, but not establishing the basis for prosecuting all those individuals associated with acts of piracy committed on the high seas. Under this view, the United States would begin prosecuting pirate negotiators - assuming personal jurisdiction can be achieved - but would not attempt to prosecute the investors, kingpins, and political elite whose acts not only make piracy possible, but profitable too.

319. Id.

320. See id. at 937 (holding that the prosecution of defendant, Ali, for aiding and abetting piracy based on acts not committed on the high seas was consistent with the law of nations); United States v. Shibin, 722 F.3d 233, 241 (4th Cir. 2013) (holding that the defendant, Shibin, could be prosecuted as an aider and abettor of piracies of German and American vessels, which took place on the high seas).

321. UNCLOS, supra note 58, art. 101(c).

322. Under 18 U.S.C. $\S \S 1651$ and 2(a), "[a]ll that is necessary is to show some affirmative participation which at least encourages the principal offender to commit the offense, with all its elements, as proscribed by the statute." Ali, 718 F.3d at 936 (quoting United States v. Raper, 676 F.2d 841, 850 (D.C. Cir. 1982)) (alteration added). 
Third, and the position taken by this Note, federal prosecutors in the United States could interpret the holdings of Shibin and Ali as establishing the legal basis for prosecuting pirate negotiators consistent with principles of international law and universal jurisdiction, but treat the cases as anomalies. The cases are anomalous insofar as they allow the United States to prosecute individuals whose acts only indirectly affected the United States and who may have never entered the high seas. Under this view, federal prosecutors would recognize their legal authority to prosecute negotiators, instigators, and kingpins, but choose not to exercise the full range of their authority. Instead, US authorities would exercise prosecutorial discretion by electing to prosecute only individuals acting on the high seas while deferring the prosecution of high-ranking pirates to the larger international community.

On a whole, the holdings in Ali and Shibin at the federal appellate level serve as victories for federal prosecutors. However, this Note interprets those cases as anomalies. When the only basis for jurisdiction is universality, federal prosecutors should only prosecute an individual who facilitates acts of piracy if that individual acts while on the high seas. ${ }^{323}$ First, this policy would adhere more closely to the policy rationales underlying universal jurisdiction. Second, it would foster respect for Somali territorial jurisdiction by deferring to the larger international community to prosecute the high-ranking pirates.

\section{A. The Rationale Behind the Exercise of Universal Jurisdiction}

The rationale underlying the theory of universal jurisdiction favors imposing discretionary limitations on prosecutions conducted pursuant to 18 U.S.C. $\S \S 1651$ and 2. Opponents of the high seas requirement have argued that, because pirate negotiators facilitate indiscriminate acts of piracy that occur on the high seas, and because the pirates acting on the high seas do not discriminate against their victim's nationality, then all states have an interest in prosecuting both the pirates committing the acts of violence, and the negotiators involved. ${ }^{324}$ This argument, however, is at odds with one of the most longstanding principles behind the crime of piracy - that the crime of piracy, as an international crime, is subject to the jurisdiction of all states. ${ }^{325}$

323. To be sure, the situation would be much different if the United States had a direct interest in the prosecution. If the captive ship were a US-flagged vessel, for example, then the United States would have a greater incentive to prosecute all those who facilitated the act of piracy. However, when the basis for jurisdiction is universality, then the connection becomes more tenuous, and the United States has less of an incentive to prosecute individuals acting from locations other than the high seas.

324. See generally Government's Response, Shibin, supra note 262.

325. See Dickinson, supra note 81 , at 335. 
When piracy occurs on the high seas every state has an interest in seeing the perpetrator prosecuted, but no individual state has territorial jurisdiction. ${ }^{326}$ When a pirate boss finances a piracy operation while in the territorial jurisdiction of Somalia, the United States - with no jurisdictional nexus to the act of piracy — would be violating this rationale by prosecuting him on a theory of universal jurisdiction. One who acts from within the territorial jurisdiction of a state is, by definition, still subject to the territorial jurisdiction of the state within which the act occurred. ${ }^{327}$ To be sure, multiple states may assert competing claims to jurisdiction over a single criminal act. ${ }^{328}$ Even though Somalia may lack the resources or political will to prosecute pirates acting from within its territorial waters, it still has jurisdiction over these criminal acts. ${ }^{329}$ To be clear, the flag state ${ }^{330}$ of the victim ship, the state to which the crew members belong, or the state of Somalia itself, may have jurisdiction over acts occurring in Somali territorial waters. In fact, UNCLOS article 100 contemplates a duty for all states to cooperate in the repression of piracy. ${ }^{331}$ Consequently, if Somalia has territorial jurisdiction over acts that occur within its territorial waters and the only basis for US jurisdiction is a theory of universal jurisdictionwithout any closer jurisdictional nexus - then a US prosecution would impinge the territorial sovereignty of Somalia. ${ }^{332}$

Second, one might argue that the exercise of universal jurisdiction over higher-ups in the piracy hierarchy can be rationalized under a "denationalization" theory, or the notion that when an individual commits an act of piracy he or she relinquishes his or her nationality. ${ }^{333}$ The "denationalization" theory, however, also fails to explain how universal jurisdiction can extend into Somali territorial waters. The "denationalization" theory is premised on the notion that an act of piracy obviates an individual's nationality, and therefore, removes the ability of a state to prosecute that individual under a national basis of jurisdiction. ${ }^{334}$ Turning to U.S. v. Ali as an example, the "de-nationalization" theory makes

326. GeISs \& PETRIG, supra note 91, at 151; Kontorovich, supra note 88, at 252.

327. See supra Part II (A)(1)-(2) for a discussion of the definition of territorial jurisdiction.

328. Kontorovich, supra note 78, at 188.

329. S.C. Res. 2020, supra note 36, ๆ 6 (“[r]eaffirming its respect for the sovereignty, territorial integrity, political independence and unity of Somalia") (alteration added).

330. See UNCLOS, supra note 58, art. 91 (establishing that "ships have the nationality of the State whose flag they are entitled to fly").

331. UNCLOS, supra note 58, art. 100 ("All States shall cooperate to the fullest possible extent in the repression of piracy on the high seas or in any other place outside the jurisdiction of any State.").

332. See supra Part II (A)(1)-(2) for a discussion of the definition of universal jurisdiction.

333. GeIss \& PETRIG, supra note 91, at 146.

334. GeIss \& PETRIG, supra note 91 , at 146. 
little sense as a basis for universal jurisdiction. More than a year after Ali negotiated a ransom from the Clipper Group, he was appointed General of the Ministry of Education in Somaliland. ${ }^{335}$ In light of Ali's position of prominence in Somaliland in June of 2010, it seems improbable to suggest that he somehow ceased to be a citizen of Somalia after he negotiated a ransom in January of 2009. In fact, piracy is such a ubiquitous profession in Somalia that it is hard to image that any Somali pirate loses citizenship merely by participating in acts of piracy. ${ }^{336}$ The "de-nationalization" theory falls short of explaining how universal jurisdiction is applicable to pirate negotiators, or more importantly those individuals who act from the Somali mainland to enable piracy.

Both the geographic limitation and the "de-nationalization" rationales for universal jurisdiction fail to explain how universal jurisdiction should be exercised over pirate enablers. Indeed, the opposite seems true: the geographic rationale for universal jurisdiction only seems to gain traction when it is limited to the "high seas." The traditional rationales for exercising universal jurisdiction favor limiting prosecutions to acts that occur on the high seas.

\section{B. Respecting Somali Territorial Jurisdiction by Deferring to the International Community}

As a matter of international policy, using US federal courts to prosecute acts of intentional facilitation that occur within the territorial waters of a state, or on a state's mainland, seems to invade the providence of Somali sovereignty and has the potential to produce absurd results. Opponents of the high seas requirement have argued that extending liability to those "inciting or intentionally facilitating" 337 piracy on dry land could allow prosecutors to charge pirate financiers and kingpins with the crime of piracy. ${ }^{338}$ The cases of U.S. v. Shibin and U.S. v. Ali seem to provide a strong legal basis for this position. ${ }^{339}$ At first glance, the benefits of prosecuting individuals higher up on the piracy hierarchy may seem enticing - such prosecutions would provide a significant disincentive to finance piracy operations by effectively attacking piracy at its source. ${ }^{340}$

335. United States v. Ali, 870 F. Supp. 2d 10, 17 (D.D.C. 2012).

336. See Lang Report, supra 2, at 13-15 (discussing the ubiquitous nature of piracy in Somali society, culture, and economy).

337. UNCLOS, supra note 58, art. 101(c).

338. Guilfoyle, supra note 262; see also Bellish, supra note 303.

339. See United States v. Ali, 885 F. Supp. 2d 17, 21 (D.D.C. 2012), opinion vacated in part, 885 F. Supp. 2d 55 (D.D.C. 2012), rev'd in part, 718 F.3d 929 (D.C. Cir. 2013), and aff'd in part, 718 F.3d 929 (D.C. Cir. 2013); United States v. Shibin, 722 F.3d 233 (4th Cir. 2013).

340. Thomas Kelly Remarks, supra note 8; see also S.C. Res. 2020, supra note 36 ("Recognizing the need to investigate and prosecute not only suspects captured at sea, but 
Other commentators have already expressed trepidation at the prospect of expanding liability in such a way. ${ }^{341}$ If someone negotiating a ransom on dry land is a pirate, then who else can be subject to criminal liability? Simply put, where does criminal liability end?

The US government has argued that "[o]nce a nation has jurisdiction over a crime ... it has jurisdiction over all those who participated in the crime, regardless of the location where those co-conspirators acted." ${ }^{\text {342 }}$ The government's position seems to contemplate a truly broad basis for the assertion of universal jurisdiction. In Shibin, the government reasoned that "Shibin participated in crimes against the international community, and justice for those crimes stops at no national boundary.",343

The government's theory relies on the following argument: assuming that a pirate financier or kingpin can be brought into the United States, as is required under 18 U.S.C. $\S 1651$, the government would charge that individual under both 18 U.S.C. $\S 1651$ and 18 U.S.C. $\S 2$. The latter provides: "[w]hoever commits an offense against the United States or aids, abets, counsels, commands, induces or procures its commission, is punishable as a principal.", 344 The "offense against the United States" would be piracy under the "law of nations" as provided in 18 U.S.C. $\S 1651$. The "law of nations" definition of piracy contained in 18 U.S.C. $\S 1651$ is provided in UNCLOS article 101(c), which in turn explicitly references acts contained in UNCLOS article 101(a) and (b). Subsection (a) categorizes as piracy "acts of violence or detention . . . on the high seas." 345 Thus, someone who has committed an act of "incite[ment] or intentional[] facilitat[ion]" of an "act[] of violence or detention" has also committed piracy under the "law of nations." "346 The government reasons that those who "aid[], abet[], counsel[], command[], induce[] or procure[]" acts under UNCLOS article 101(a) or (b) can be charged with piracy, as principals, under 18 U.S.C. $\S \S 1651$ and 2; and because $\S 2$ contains no high seas requirement, they can be convicted of the crime of piracy itself. ${ }^{347}$

Prosecuting the enablers of piracy - the financiers, kingpins, and politicians-under UNCLOS article 101(c) and 18 U.S.C. $\S \S 1651$ and 2, seems to stretch the definition of piracy, and the limits of universal jurisdiction, to the point of producing absurd results. First, it seems to cross a careful line drawn by the UN Security Council: "[r]eaffirming its respect

\footnotetext{
also anyone who incites or intentionally facilitates piracy operations, including key figures of criminal networks involved in piracy who illicitly plan, organize, facilitate, or finance and profit from such attacks. ...") (alteration added).

341. See Volokh, supra note 54.

342. Government's Response, Shibin, supra note 262.

343. Government's Response, Shibin, supra note 262.

344. 18 U.S.C. § 2(a).

345. UNCLOS, supra note 58, art. 101.

346. Id.

347. See Government's Response, Shibin, supra note 262.
} 
for the sovereignty, territorial integrity, political independence and unity of Somalia. . . "348 This resolution is violated when the United States prosecutes individuals for acts that occur solely within Somali territorial jurisdiction and from within the Somali mainland. Second, allowing states to exercise universal jurisdiction over acts occurring in territorial jurisdictions diminishes predictability by erasing a clear end to liability. Pirate financing often occurs through a pirate committee which is comprised of investors and commanders who help prepare and carry out both sea and terrestrial operations. ${ }^{349}$ Often, accountants support the investors and managers while the actual pirate operations are supplied by Somali cooks. ${ }^{350}$ Under the broad jurisdictional interpretation offered by the government in Shibin an accountant on the Somali mainland who tabulates and distributes profits for a pirate financier has seemingly "aid[ed]" in piracy under 18 U.S.C. $\S \S 1651$ and 2. Likewise, a Somali cook living in Mogadishu, who prepares food for a piracy raid, could, if brought into the United States, be convicted of "aiding"ipiracy under 18 U.S.C. $\S \S 1651$ and $2 .{ }^{351}$ These hypothetical scenarios highlight the anomalous nature of the holdings in United States v. Ali and United States v. Shibin.

If liability can extend to individuals who act on dry land, there is a concern about the discretionary power of a state to expand liability to acts that have traditionally not been considered piracy. As Chief Justice John Marshall put it:

A pirate, under the laws of nations, is an enemy of the human race. Being the enemy of all, he is liable to be punished by all. . . . But piracy, under the law of nations, which alone is punishable by all nations, can only consist in an act which is an offense against all. No particular nation can increase or diminish the list of offenses thus punishable. $^{352}$

To be sure, the question of whether to prosecute a pirate accountant or a Somali cook is still a matter of prosecutorial discretion, pursuant to

348. S.C. Res. 2020, supra note 36, 16 (emphasis added).

349. U.N. Security Council, Letter dated 18 July 2011 from the Chairman of the Security Council Committee pursuant to resolutions 751 (1992) and 1907 (2009) concerning Somalia and Eritrea addressed to the President of the Security Council, 228, U.N. Doc. S/2011/433 (July 18, 2011) [hereinafter U.N. Security Council letter]; see also Geopolicity, The Economics of Piracy: Pirate Ransoms \& Livelihoods off the Coast of Somalia 6-8 (2011), archived at http://perma.cc/8N9U-T7PC (detailing the pirate value chain model through consideration of both sea and land based support activities).

350. U.N. Security Council letter, supra note 349.

351. See Volokh, supra note 54 (asking, "what about the guys who sell food to Somali pirates?").

352. United States v. Ali, 885 F. Supp. 2d 17, 27 (D.D.C. 2013). 
UNCLOS article 105 and state municipal law. This Note recommends exercising prosecutorial discretion to impose limitations upon the kinds of acts that should be prosecuted under 18 U.S.C. $\S \S 1651$ and 2, while deferring to the international community to bring high-ranking pirates to justice.

Finally, the marginal cost to the United States of prosecuting pirate enablers seems to substantially outweigh the negligible benefit. An estimated 70 to 86 percent of ransom proceeds go to the instigators and individuals providing tacit political support to pirate networks. ${ }^{353}$ This means that the vast majority of the piracy proceeds go to individuals who likely never have to enter the high seas. The current, yearly cost of naval operations is estimated at more than $\$ 1$ billion, ${ }^{354}$ and the cost of securing ships with armed guards is about $\$ 50,000$ per vessel. ${ }^{355}$ Moreover, the twenty counties that have arrested, detained, or tried Somali pirate suspects, spent about \$16.4 million to prosecute and imprison those Somalis suspected of piracy in 2011 alone. ${ }^{356}$ The benefit, to the United States, of using universal jurisdiction to prosecute pirates is likely low; in fact, at least one commentator has argued that using universal jurisdiction to prosecute pirates is economically inefficient. ${ }^{357}$ When a county uses universal jurisdiction to prosecute a pirate, the prosecuting country removes a negative externality from the globe, while internalizing the cost of the prosecution. ${ }^{358}$ In other words, " $\left.\mathrm{t}\right]$ he prosecuting state bears all the cost of a complex prosecution, while the entire community of nations benefit from the deterrent effect of that prosecution on future pirates." 359 Any benefit the United States derives from prosecuting pirate enablers is likely outweighed by the cost of carrying out the prosecution - that is, when the basis for jurisdiction is universality.

Prosecuting pirate enablers under universal jurisdiction is further inadvisable given that the international community is already taking steps to disrupt the efforts of high-ranking pirates. Working Group 5 of the Contact Group on Piracy off the Coast of Somalia has facilitated the coordination of the sixty countries and twenty international organizations working to combat the scourge of piracy. ${ }^{360}$ Working Group 5 has ramped up efforts to identify and interrupt the financial networks of pirates by building up anti-

353. Pirates of Somalia: Ending the Threat, supra note 7, at 118.

354. Pirates of Somalia: Ending the Threat, supra note 7, at 168.

355. Pirates of Somalia: Ending the Threat, supra note 7, at 168.

356. BOWDEN \& BASNET REPORT, supra note 5, at 2.

357. Jonathan Bellish, A High Seas Requirement for Inciters and Intentional Facilitators of Piracy Jure Gentium and Its (Lack of) Implications for Impunity, 15 SAN DIEGO INT'L L.J. (forthcoming 2013) (manuscript at 43), archived at http://perma.cc/LM9Z-ZRX6.

358. Id.

359. Id.

360. Pirates of Somalia: Ending the Threat, supra note 7, at xxi, xxii. 
money laundering regulations and implementing regional programs, aimed at disrupting financial flows into piracy networks. ${ }^{361}$ The United States should defer to the international community because the cost of combating piracy is very high, and because the international community, through organizations like Working Group 5, is better poised to fight the scourge of piracy on the Somali mainland.

Outlining a specific, international plan to deal with the prosecution of "white-collar" acts of pirates is well beyond the scope of this Note. Instead, this Note recommends that the United States consider some of the potential deleterious effects of relying on a theory of universal jurisdiction to prosecute high-ranking pirates who never personally act on the high seas. Such a consideration favors limiting piracy prosecutions to those individuals who act on the high seas.

\section{CONCLUSION}

The United States should exercise discretion and defer to the international community to prosecute high-ranking pirates. Although the United States has an interest in prosecuting pirate negotiators, kingpins, and financiers, the policy rationale for universal jurisdiction, a respect for Somali territorial jurisdiction, and practical concerns about the sustainability of prosecuting high-ranking pirates all favor deference to a unified international solution. To be sure, the benefits of prosecuting highranking pirates are appealing at first blush; however, this Note raises some cautionary advice - relying on universal jurisdiction to combat Somali piracy may, in some circumstances, undermine the very international framework the United States seeks to uphold.

361. Pirates of Somalia: Ending the Threat, supra note 7, at 160. 